\title{
Antioxidant Food Components for the Prevention and Treatment of Cardiovascular Diseases: Effects, Mechanisms, and Clinical Studies
}

\author{
Dan-Dan Zhou $\mathbb{D}^{1},{ }^{1}$ Min Luo $\mathbb{D}^{1}{ }^{1}$ Ao Shang $\mathbb{D},{ }^{1}$ Qian-Qian Mao $\mathbb{D}^{1},{ }^{1}$ Bang-Yan Li $\mathbb{D},^{1}$ \\ Ren-You Gan $\mathbb{D}^{2},{ }^{1}$ and Hua-Bin $\mathrm{Li}\left({ }^{1}\right.$ \\ ${ }^{1}$ Guangdong Provincial Key Laboratory of Food, Nutrition, and Health, Department of Nutrition, School of Public Health, Sun Yat- \\ sen University, Guangzhou 510080, China \\ ${ }^{2}$ Research Center for Plants and Human Health, Institute of Urban Agriculture, Chinese Academy of Agricultural Sciences, \\ Chengdu 610213, China
}

Correspondence should be addressed to Hua-Bin Li; lihuabin@mail.sysu.edu.cn

Received 10 December 2020; Revised 9 January 2021; Accepted 15 January 2021; Published 29 January 2021

Academic Editor: Guodong Zhang

Copyright ( 2021 Dan-Dan Zhou et al. This is an open access article distributed under the Creative Commons Attribution License, which permits unrestricted use, distribution, and reproduction in any medium, provided the original work is properly cited.

Cardiovascular diseases (CVDs) have gained increasing attention because of their high prevalence and mortality worldwide. Epidemiological studies revealed that intake of fruits, vegetables, nuts, and cereals could reduce the risk of CVDs, and their antioxidants are considered as the main contributors. Moreover, experimental studies showed that some antioxidant natural products and their bioactive compounds exerted beneficial effects on the cardiovascular system, such as polyphenols, polysaccharides, anthocyanins, epigallocatechin gallate, quercetin, rutin, and puerarin. The mechanisms of action mainly included reducing blood pressure, improving lipid profile, ameliorating oxidative stress, mitigating inflammation, and regulating gut microbiota. Furthermore, clinical trials confirmed the cardiovascular-protective effect of some antioxidant natural products, such as soursop, beetroot, garlic, almond, and green tea. In this review, we summarized the effects of some antioxidant natural products and their bioactive compounds on CVDs based on the epidemiological, experimental, and clinical studies, with special attention paid to the relevant mechanisms and clinical trials.

\section{Introduction}

Cardiovascular diseases (CVDs), such as coronary heart disease (CHD), hypertensive heart disease, heart failure, and stroke, are the leading cause of death worldwide [1]. CVDs could be caused by hypertension, dyslipidemia, atherosclerosis, oxidative stress, inflammation, and enteric dysbacteriosis [2-4]. Several synthetic drugs have been used to treat CVDs, but they showed some adverse effects, such as gastrointestinal reaction, hyperkalemia, and arrhythmias $[5,6]$. On the other hand, accumulating evidence has shown that some antioxidant natural products could be a safe and effective alternative for the prevention and treatment of CVDs [7-11].

Natural products are rich in dietary fibers, polyphenols, vitamins, minerals, and other beneficial components, and possess many bioactivities, such as antioxidant, anti-inflam- matory, anticancer, antidiabetic, antiobesity, hepatoprotective, immunoregulatory, antibacterial, and cardiovascularprotective effects [12-20]. Epidemiological studies found that people consuming more fruits, vegetables, teas, cereals, and nuts had a lower risk of CVDs, and the antioxidants in these natural products were considered as the main contributors [21-23]. Additionally, experimental researches showed that some antioxidant natural products and their active compounds could prevent and treat CVDs through different mechanisms of action [24-32]. Furthermore, clinical trials provided more reliable human evidence on some antioxidant natural products for the prevention and treatment of CVDs $[33,34]$. The purpose of this review is to summarize the effect of some antioxidant natural products and their bioactive compounds on CVDs from the results of epidemiological, experimental and clinical studies in the last five years, and 
special attention was paid to the mechanisms of action and clinical trials.

\section{Epidemiological Studies}

Increasing epidemiological studies have suggested that the intake of some antioxidant natural products significantly attenuated the risk factors of CVDs (Table 1).

Several cross-sectional studies found that some dietary plants were beneficial for the prevention and management of CVDs. For instance, a cross-sectional study of 18,757 Chinese adolescents aged 13-17 years revealed that daily intake of at least 3 servings of vegetables (1 serving of vegetable was the size of an adult's fist) lowered the risk of hypertension (odds ratio $(\mathrm{OR})=0.74 ; 95 \%$ confidence interval $(\mathrm{CI})$ : 0.42-0.95) compared with daily consumption of vegetable $<1$ serving [35]. Additionally, an analysis of 18,433 American adults found that compared with the lowest tertile consumption of cereals, vegetables, and fruit fibers as well as their total fiber, the OR $(95 \% \mathrm{CI})$ of hypertension for the highest tertile were 0.80 (0.69-0.98), 0.82 (0.69-0.98), 0.86 (0.71-1.04), and 0.62 (0.52-0.75), respectively, indicating that cereals, vegetables, and total fibers were inversely related with hypertension, but fruit fiber was not [36]. Moreover, the data from the Korea National Health and Nutrition Examination Survey showed that overweight older males and younger females who consumed a moderate amount of curry (2-3 times a month or once a week), mainly composed of turmeric, had significantly lower levels of blood glucose and triglyceride (TG) than a group who had low curry consumption (almost never, or once a month) [37].

A negative correlation between the intake of several edible plants and the incidence as well as mortality of CVDs was also observed in some cohort studies. A follow-up study recruiting 521,891 Chinese adults aged 30-79 years reported that participants who consumed fresh fruit daily had lower systolic blood pressure (SBP) and blood glucose level compared to those who never or rarely ate fresh fruit. The HR ( $95 \%$ CI) for cardiovascular death, incident major coronary events, ischemic stroke, and hemorrhagic stroke were 0.60 (0.54-0.67), $0.66(0.58-0.75), 0.75(0.72-0.79)$, and 0.64 (0.52-0.74), respectively, elucidating the protective effect of fresh fruit on the cardiovascular system [38]. Moreover, another analysis of 3,052 adults indicated that the habitual consumption of allium vegetables, such as garlic and onion, was related to a $64 \%$ decreased risk of CVD outcomes (HR $=0.36$; 95\% CI: 0.18-0.71) [39]. Additionally, a cohort study of young Mediterranean populations found that compared to the lowest quintile of fruit intake or whole grain intake, the HR (95\% CI) of the risk of CVD events for the highest quintile were 0.51 (0.27-0.95) and 0.43 (0.20-0.93), respectively, showing the benefits of fruit or whole grain to prevent CVDs [40]. Furthermore, a prospective study of 2,295 Iranian adults pointed out that compared to the lowest tertile of dietary fiber intakes from grains, legumes, nuts, fruits, and vegetables, the hazard ratios (HR) (95\% CI) of CVD risks for the highest tertile were 0.90 (0.44-1.86), 0.31 (0.15-0.65), 0.49 (0.24-1.02), 0.44 (0.22-0.89), and 0.34 $(0.16-0.72)$, respectively, suggesting that dietary fiber from legumes, fruits, and vegetables were negatively related to CVDs, while fiber from grains and nuts had no significant association with CVDs [41]. However, a cohort study found that nut intake significantly lowered the risk of CVDs [42]. The reason could be that it was not fiber but other bioactive compounds in nuts that play a vital role in the prevention of CVDs, or that there were disparities of population, study design, and confounding factors in different studies, which need to be further investigated in the future.

In short, the collected epidemiological investigations illuminated the protective effects of some antioxidant natural products and their bioactive components on CVDs, although there were inconsistent results. In addition, based on the beneficial role of some plants in CVDs, it is advisable to increase the intake of some plant-based foods, such as fresh fruits, vegetables, legumes, cereals, and nuts, to reduce the risk of CVDs.

\section{Experimental Studies}

Many experimental studies investigated the effects of some antioxidant natural products and their bioactive compounds on CVDs (Table 2), and the relevant mechanisms are discussed below (Figure 1).

3.1. Reducing Blood Pressure. It's widely known that hypertension is an important risk factor for CVDs [56]. An analysis pointed out that every $10 \mathrm{~mm} \mathrm{Hg}$ reduction in SBP markedly decreased the risk of major cardiovascular disease events in patients with a history of CVDs [57]. Some natural products are effective in the prevention and treatment of CVDs via reducing blood pressure. The hypotensive effect of these natural products was mainly related to the regulation of the renin-angiotensin system (RAS) and the release of nitric oxide (NO).

3.1.1. Regulating the Renin-Angiotensin System. Blood pressure regulation is a sophisticated process involving various organs and systems, among which RAS plays an important role in elevating blood pressure [58]. Regulating the activity of RAS, such as inhibiting the synthesis of angiotensin-1 converting enzyme (ACE) as well as the secretion of renin/angiotensin, is helpful to ameliorate blood pressure [59, 60]. Many experimental studies revealed that some natural products performed the blood pressure lowering efficacy mainly though the regulation of RAS. For example, a study showed a potent in vitro ACE inhibitory property of winged bean seed hydrolysate, as well as the in vivo hypotensive effect of the hydrolysate in a dose-dependent manner in SpragueDawley (SD) rats, indicating that the hydrolysate lowered blood pressure via suppressing the activity of ACE [61]. Another study found that Solanum macrocarpon leaf extract suppressed the in vitro activities of renin and ACE. The oral administration of the extract decreased SBP, diastolic blood pressure (DBP), and heart rate in spontaneously hypertensive rats. Rutin, caffeic acid, and myricetin were the major polyphenols in the extract [62]. Furthermore, a study pointed out that Ocimum sanctum and Citrus paradisi infusions possessed a hypotensive property. The infusion of Ocimum 
TABLE 1: The effects of antioxidant natural products on CVDs from epidemiological studies.

\begin{tabular}{|c|c|c|c|c|c|}
\hline Plants & Components & Study type & Subjects & Results & Ref. \\
\hline Fruit & NA & Cohort study & 512,891 Chinese & $\begin{array}{l}\text { Lowering SBP and blood glucose, reducing the risks } \\
\text { of cardiovascular death (HR: 0.60; } 95 \% \text { CI, } \\
0.54-0.67 \text { ), incident major coronary event (HR: } \\
0.66 ; 95 \% \text { CI, 0.58-0.75), ischemic stroke (HR: } 0.75 \text {; } \\
\text { 95\% CI, 0.72-0.79), and hemorrhagic stroke } \\
\text { (HR: } 0.64 \text {; } 95 \% \text { CI, } 0.56-0.74)\end{array}$ & {$[38]$} \\
\hline Fruit & NA & Cross-sectional study & 1,590 adults & $\begin{array}{c}\text { Low fruit consumption was associated with } \\
\text { increased BP in 50-59-year-old group (PR: 1.62; } \\
95 \% \text { CI, 1.09-2.41) }\end{array}$ & {$[43]$} \\
\hline Fruit & $\begin{array}{l}\text { Anthocyanin, } \\
\text { flavanone }\end{array}$ & Cohort study & 43.880 healthy men & $\begin{array}{l}\text { Higher anthocyanin intake was inversely associated } \\
\text { with nonfatal myocardial infarction (HR: } 0.87 ; 95 \% \\
\text { CI, } 0.75-1.00 \text { ). Higher flavanone intake was } \\
\text { inversely associated with ischemic stroke (HR: } 0.78 \text {; } \\
\text { 95\% CI, 0.62-0.97). }\end{array}$ & {$[44]$} \\
\hline Fruit & Flavone & Cross-sectional study & $\begin{array}{l}7,963 \text { women aged } \\
\geq 30 \text { years }\end{array}$ & $\begin{array}{l}\text { Inversely associated with SBP, TG, and } \\
\text { TG/HDL-C. }\end{array}$ & {$[45]$} \\
\hline Fruit & NA & Cohort study & $\begin{array}{l}\text { 70,047 Chinese adults } \\
\text { with CVD or } \\
\text { hypertension }\end{array}$ & $\begin{array}{l}\text { Inversely associated with CVD mortality (HR: 0.79; } \\
\qquad 95 \% \mathrm{CI}, 0.73-0.86)\end{array}$ & {$[46]$} \\
\hline Fruit & NA & Cross-sectional study & $\begin{array}{l}9,040 \text { subjects aged } \\
\geq 25 \text { years }\end{array}$ & $\begin{array}{l}\text { Inversely associated with CVD (OR: } 0.86 ; 95 \% \mathrm{CI} \text {, } \\
\qquad 0.74-0.98)\end{array}$ & {$[47]$} \\
\hline Vegetable & NA & Cross-sectional study & 18,757 adolescents & $\begin{array}{l}\text { Consuming } \geq 3 \text { servings of vegetables lowered the } \\
\text { risk of hypertension (OR: } 0.74 ; 95 \% \text { CI, 0.58-0.94) }\end{array}$ & [35] \\
\hline Vegetable & Nitrate & Cohort study & $\begin{array}{l}2,229 \text { Australian aged } \\
\geq 39 \text { years }\end{array}$ & $\begin{array}{l}\text { Inversely associated with CVD mortality } \\
\text { (comparison of <69.5 mg/day intake of vegetable, } \\
69.5-99.6 \mathrm{mg} / \text { day (HR: } 0.53 ; 95 \% \mathrm{CI}, 0.35-0.82 \text { ), } \\
\text { 99.7-137.8 mg/day (HR: } 0.51 ; 95 \% \mathrm{CI}, 0.32-0.80 \text { ), } \\
\text { and }>137.8 \mathrm{mg} / \text { day (HR: } 0.63 ; 95 \% \mathrm{CI}, 0.41-0.95 \text { ) }\end{array}$ & {$[48]$} \\
\hline Allium vegetable & NA & Cohort study & $\begin{array}{l}\text { Adult men and } \\
\text { women }\end{array}$ & $\begin{array}{l}\text { Associated with a } 64 \% \text { reduced risk of CVD } \\
\text { outcomes (HR: } 0.36 ; 95 \% \text { CI, } 0.18-0.71 \text { ) }\end{array}$ & [39] \\
\hline Nut & NA & Cohort study & $\begin{array}{l}16,217 \text { participants } \\
\text { with diabetes mellitus }\end{array}$ & $\begin{array}{c}\text { Inversely associated with the total CVD incidence } \\
\text { (HR: } 0.83 ; 95 \% \mathrm{CI}, 0.71-0.98) \text {, CHD incidence (HR: } \\
0.80 ; 95 \% \mathrm{CI}, 0.67-0.96 \text { ), and CVD mortality (HR: } \\
0.66 ; 95 \% \mathrm{CI}, 0.52-0.84)\end{array}$ & [49] \\
\hline Nut & NA & 3 large cohort studies & $\begin{array}{l}76,364 \text { women } \\
92,946 \text { women } \\
41,526 \text { men }\end{array}$ & $\begin{array}{c}\text { Inversely associated with the total CVD (HR: } 0.86 \text {; } \\
\text { 95\% CI, 0.79-0.93) and CHD (HR: 0.80; 95\% CI, } \\
0.72-0.89)\end{array}$ & {$[50]$} \\
\hline Nut & NA & 3 large cohort studies & $\begin{array}{l}34,103 \text { men } \\
77,815 \text { women } \\
80,737 \text { women }\end{array}$ & $\begin{array}{l}\text { Inversely associated with CVD (RR: } 0.92 ; 95 \% \text { CI, } \\
0.86-0.98 \text { ), CHD (RR: 0.94; 95\% CI, 0.89-0.99), and } \\
\text { stroke (RR: } 0.89 ; 95 \% \text { CI, 0.83-0.95) }\end{array}$ & {$[51]$} \\
\hline Nut & NA & Cohort study & 61,364 Swedish adults & $\begin{array}{c}\text { Inversely associated with risk of heart failure and } \\
\text { atrial fibrillation } \\
\text { 1-3 times/month: heart failure (HR: } 0.87 ; 95 \% \mathrm{CI} \text {, } \\
0.80-0.94 \text { ) and atrial fibrillation (HR: } 0.97 ; 95 \% \mathrm{CI} \text {, } \\
0.93-1.02 \text { ) } \\
\text { 1-2 times/week: heart failure (HR: } 0.80 ; 95 \% \mathrm{CI} \text {, } \\
0.67-0.97 \text { ) and atrial fibrillation (HR: } 0.88 ; 95 \% \mathrm{CI} \text {, } \\
0.79-0.99 \text { ) } \\
3 \text { times/week: heart failure (HR: } 0.98 ; 95 \% \mathrm{CI} \text {, } \\
0.76-1.27 \text { ) and atrial fibrillation (HR: } 0.82 \text {; } \\
95 \% \text { CI, } 0.68-0.99)\end{array}$ & {$[42]$} \\
\hline Legume & NA & Cohort study & $\begin{array}{l}\text { 6,504 Iranian middle- } \\
\text { aged and older people }\end{array}$ & $\begin{array}{l}\text { Inversely related to the risk of CVD events in } \\
\text { old-aged Iranians (HR: } 0.66 \text {; } 95 \% \mathrm{CI}, 0.45-0.98 \text { ) } \\
\text { but not in middle-aged Iranians }\end{array}$ & {$[52]$} \\
\hline Curry (turmeric) & Curcumin & Cross-sectional study & $\begin{array}{l}\text { Individuals aged } 19- \\
\quad 64 \text { years }\end{array}$ & Lowering blood glucose and TG levels & {$[37]$} \\
\hline
\end{tabular}


TABLE 1: Continued.

\begin{tabular}{|c|c|c|c|c|c|}
\hline Plants & Components & Study type & Subjects & Results & Ref. \\
\hline Fruit, vegetable & NA & Cross-sectional study & $\begin{array}{l}1,596 \text { adolescents and } \\
\text { young people in } \\
\text { Tanzania and Uganda }\end{array}$ & $\begin{array}{l}\text { Lowering the risk of hypertension (OR: } 0.7 ; 95 \% \\
\text { CI, } 0.50-0.98)\end{array}$ & {$[53]$} \\
\hline Fruit, vegetable & NA & Cross-sectional study & $\begin{array}{l}229 \text { patients with } \\
\text { primary hypertension }\end{array}$ & Lowering $\mathrm{BP}$, heart rate, and $\mathrm{BMI}$ & {$[54]$} \\
\hline Fruit, vegetable & NA & Cohort study & $\begin{array}{l}\text { 2,354 Ugandan } \\
\text { newborns }\end{array}$ & Lowering BP & {$[21]$} \\
\hline Fruit, vegetable & NA & Cohort study & 8,997 aging subjects & $\begin{array}{c}\text { Fruit intake was inversely associated with BP but } \\
\text { vegetable intake was not }\end{array}$ & {$[55]$} \\
\hline $\begin{array}{l}\text { Fruit, whole } \\
\text { grain }\end{array}$ & Fiber & Cohort study & $\begin{array}{l}17,007 \text { young } \\
\text { Mediterranean } \\
\text { participants }\end{array}$ & $\begin{array}{l}\text { Fruit (HR: } 0.51 ; 95 \% \text { CI, } 0.27-0.95 \text { ) or whole grain } \\
\text { (HR: } 0.43 ; 95 \% \text { CI, } 0.20-0.93 \text { ) intake was inversely } \\
\text { associated with CVD events. }\end{array}$ & {$[40]$} \\
\hline $\begin{array}{l}\text { Fruit, vegetable, } \\
\text { cereal }\end{array}$ & Fiber & Cross-sectional study & $\begin{array}{l}\text { 18,433 American } \\
\text { adults }\end{array}$ & $\begin{array}{c}\text { Total fiber (OR: 0.62; 95\% CI, 0.52-0.75), cereal } \\
\text { fiber (OR: 0.80; 95\% CI, 0.69-0.98), and vegetable } \\
\text { fiber (OR: 0.82; 95\% CI, 0.69-0.98) were inversely } \\
\text { associated with the risk of hypertension, but fruit } \\
\text { fiber was not }\end{array}$ & {$[36]$} \\
\hline $\begin{array}{l}\text { Fruit, vegetable, } \\
\text { legume, grain, } \\
\text { nut }\end{array}$ & Fiber & Cohort study & $\begin{array}{l}2,295 \text { health } \\
\text { professionals }\end{array}$ & $\begin{array}{c}\text { Legume fiber (HR: } 0.31 ; 95 \% \mathrm{CI}, 0.15-0.65 \text { ), fruit } \\
\text { fiber (HR: 0.44; } 95 \% \text { CI, 0.22-0.89), and vegetable } \\
\text { fiber (HR: 0.34; 95\% CI, 0.16-0.72) were inversely } \\
\text { associated with the CVD risks, but grain and nut } \\
\text { fiber were not }\end{array}$ & {$[41]$} \\
\hline
\end{tabular}

sanctum downregulated the gene expression of renin and angiotensinogen and reduced renal triglyceride accumulation and lipid/protein oxidation in SD rats, while the hypotensive effect of Citrus paradisi could be associated with other mechanisms [63].

3.1.2. Increasing the Release of NO. Accumulating evidence has proven that the generation of NO in endothelial cells is mainly activated by endothelial nitric oxide synthase (eNOS). $\mathrm{NO}$ could induce the relaxation of blood vessels, leading to the reduction of blood pressure $[64,65]$. Hence, promoting the production of NO is an effective way to decrease blood pressure, which will protect the function of the cardiovascular system. There are findings suggesting that some natural products showed an antihypertensive effect via accelerating the release of $\mathrm{NO}$, holding tremendous promise to prevent the development of hypertension and CVDs. For example, Morus alba induced endothelial vasorelaxation in mesenteric arteries via a NO-dependent pathway, and decreased blood pressure in wild-type mice. However, it failed to exert a hemodynamic effect in eNOS-deficient mice, which further testified to the antihypertensive action of Morus alba through a NO-dependent pathway [66]. Moreover, a study found that white mulberry fruit polysaccharides could provoke endothelium-dependent relaxation in rat mesenteric arteries and NO production in endothelial cells, and its intravenous injection induced the reduction of blood pressure in both normotensive rats and spontaneously hypertensive rats, while this effect was markedly attenuated in normotensive rats pretreated with the NO synthase inhibitor NG-nitro-L- arginine methyl ester (L-NAME). These results suggested that the hypotensive effect of white mulberry fruit was mediated by the NO pathway [67]. Additionally, grape seed polyphenol extract promoted the production of NO and reduced the blood pressure in hypertensive rats via upregulating the expression of eNOS and Sirtuin-1 [68].

3.2. Improving Lipid Profile. Hyperlipidemia results from the metabolic abnormalities of lipids, leading to higher levels of lipids in plasma than normal ones, which can be generally characterized as higher levels of total cholesterol (TC), triglyceride (TG), and low-density lipid protein cholesterol (LDL-C) and a lower level of high-density lipid protein cholesterol (HDL-C) [69]. Increasing evidence suggested that hyperlipidemia was closely associated with atherosclerosis, playing an important role in the development of CVDs [70, 71]. Several experimental studies revealed the hypolipidemic effect of natural products. For example, an in vivo study found that after the treatment of mung bean sprouts, the SBP and LDL-C levels of SD rats in the high-fat diet group significantly lowered to the normal level [72]. Additionally, supplementing obese rats with red dragon fruit flour for 4 weeks markedly reduced the blood glucose, TC, TG, and LDL-C levels, while HDL-C had no significant difference [73]. Also, another study found that after oral administration of red dragon fruit peel powder for 30 days, TC, TG, and LDL-C levels of hyperlipidemic male mice declined in a dose-dependent manner, accompanied by an increase in HDL-C levels [74]. The two studies above showed that both the pulp and peel of red dragon fruit possessed promising 
TABLE 2: The effects of antioxidant natural products on CVDs from experimental studies.

\begin{tabular}{|c|c|c|c|c|c|c|}
\hline Plants & Components & Study type & Subjects & Dose \& Time & Effects and mechanisms & Ref. \\
\hline $\begin{array}{l}\text { Winged bean } \\
\text { seed }\end{array}$ & Peptide & $\begin{array}{l}\text { In vitro } \\
\text { In vivo }\end{array}$ & $\mathrm{ACE}$ and $\mathrm{SD}$ rats & $\begin{array}{c}1 \mathrm{mM} \text { peptides, } 3 \mathrm{~h} ; 150 \\
\text { and } 300 \mathrm{mg} / \mathrm{kg} \mathrm{BW} \\
24 \mathrm{~h}\end{array}$ & $\begin{array}{l}\text { Inhibiting ACE activity } \\
\text { Lowering BP }\end{array}$ & [61] \\
\hline $\begin{array}{l}\text { Solanum } \\
\text { macrocarpon }\end{array}$ & Polyphenols & $\begin{array}{l}\text { In vitro } \\
\text { In vivo }\end{array}$ & SHRs & 100 and $500 \mathrm{mg} / \mathrm{kg} \mathrm{BW}$ & $\begin{array}{l}\text { Inhibiting } \mathrm{ACE} / \text { renin activities } \\
\text { Lowering } \mathrm{DBP} \text { and heart rate }\end{array}$ & {$[62]$} \\
\hline $\begin{array}{l}\text { Citrus } \\
\text { paradisi and } \\
\text { Ocimum } \\
\text { sanctum }\end{array}$ & $\begin{array}{l}\text { Epigallocatechin } \\
\text { gallate and } \\
\text { quercetin }\end{array}$ & In vivo & $\mathrm{SD}$ rats & $\begin{array}{l}2 \mathrm{~g} \text { dried ground } \\
\text { material in } 200 \mathrm{~mL} \\
\text { water, } 4 \text { months }\end{array}$ & $\begin{array}{c}\text { Reducing BP (renin and } \\
\text { angiotensinogen } \downarrow \text { ) and reducing renal } \\
\text { TG accumulation and lipid/protein } \\
\text { oxidation (Citrus paradisi) } \\
\text { Reducing BP via other mechanisms } \\
\text { (Ocimum sanctum) }\end{array}$ & {$[63]$} \\
\hline Pigeon pea & Protein & $\begin{array}{l}\text { In vitro } \\
\text { In vivo }\end{array}$ & $\mathrm{ACE}$ and SHRs & $100 \mathrm{mg} / \mathrm{kg} \mathrm{BW}, 24 \mathrm{~h}$ & $\begin{array}{c}\text { Inhibiting ACE/renin activities and } \\
\text { scavenging free radicals } \\
\text { Lowering BP }\end{array}$ & {$[24]$} \\
\hline $\begin{array}{l}\text { Ficus } \\
\text { deltoidea var. } \\
\text { Kunstleri }\end{array}$ & NA & In vivo & SHRs & $\begin{array}{l}\text { 500, } 800,1000, \text { and } \\
1300 \mathrm{mg} / \mathrm{kg} \mathrm{BW}, 4 \\
\text { weeks }\end{array}$ & $\begin{array}{l}\text { Lowering BP (ACE, angiotensin, } \\
\text { aldosterone } \downarrow \text {, and eNOS } \uparrow \text { ) and } \\
\text { improving antioxidant capacity }\end{array}$ & [97] \\
\hline $\begin{array}{l}\text { Pueraria } \\
\text { lobata }\end{array}$ & Puerarin & In vivo & SHRs & $\begin{array}{c}40 \text { and } 80 \mathrm{mg} / \mathrm{kg}, 9 \\
\text { weeks }\end{array}$ & Lowering BP (eNOS, NO, and cGMP $\uparrow$ ) & [98] \\
\hline $\begin{array}{l}\text { White } \\
\text { mulberry } \\
\text { fruit }\end{array}$ & Polysaccharides & $\begin{array}{l}\text { In vitro } \\
\text { In vivo }\end{array}$ & $\begin{array}{c}\text { Mesenteric } \\
\text { artery and } \\
\text { endothelial cells; } \\
\text { SD rats and } \\
\text { SHRs }\end{array}$ & $\begin{array}{l}0.5 \mathrm{mg} / \mathrm{mL} ; 5 \mathrm{mg} / \mathrm{kg} \\
5 \mathrm{~min}\end{array}$ & $\begin{array}{l}\text { Inducing endothelium-dependent } \\
\text { relaxation in rat mesenteric arteries and } \\
\text { NO production in endothelial cells } \\
\text { Lowering mean arterial BP }\end{array}$ & [67] \\
\hline Grape seed & Polyphenols & In vivo & $\begin{array}{l}\text { Hypertensive } \\
\text { rats }\end{array}$ & $375 \mathrm{mg} / \mathrm{kg}$ & Lowering BP (eNOS and Sirtuin-1 1 ) & {$[68]$} \\
\hline Morus alba & Rutin & $\begin{array}{l}\text { In vitro } \\
\text { In vivo }\end{array}$ & $\begin{array}{c}\text { Mesenteric } \\
\text { arteries; } \\
\text { wild-type and } \\
\text { eNOS-deficient } \\
\text { mice }\end{array}$ & $\begin{array}{l}8 \mathrm{mg} / \mathrm{mL} ; 100,200 \text {, and } \\
400 \mathrm{mg} / \mathrm{kg}\end{array}$ & $\begin{array}{l}\text { Inducing endothelial vasorelaxation via } \\
\text { a NO-dependent pathway } \\
\text { Decreasing BP in wild-type mice, not in } \\
\text { eNOS-deficient mice }\end{array}$ & [66] \\
\hline $\begin{array}{l}\text { Phyllanthus } \\
\text { niruri }\end{array}$ & NA & $\begin{array}{l}\text { In vitro } \\
\text { In vivo }\end{array}$ & $\begin{array}{l}\text { Endothelium- } \\
\text { intact/denuded } \\
\text { aorta rings; SHRs }\end{array}$ & $\begin{array}{l}0.125-4 \mathrm{mg} / \mathrm{mL} ; \\
1000 \mathrm{mg} / \mathrm{kg} \mathrm{BW}, 2 \\
\text { weeks }\end{array}$ & $\begin{array}{c}\text { Inducing vasorelaxation on } \\
\text { endothelium-intact aorta rings } \\
\text { Decreasing BP }\end{array}$ & [99] \\
\hline $\begin{array}{l}\text { Scutellaria } \\
\text { baicalensis } \\
\text { Georgi }\end{array}$ & Baicalin & $\begin{array}{l}\text { In vitro } \\
\text { In vivo }\end{array}$ & $\begin{array}{l}\text { Thoracic aortas; } \\
\text { SHRs }\end{array}$ & $\begin{array}{l}0.1 \mathrm{mg} / \mathrm{mL} ; 10,50,100 \\
\text { and } 200 \mathrm{mg} / \mathrm{kg} \mathrm{BW}, 0 \\
30,60,90 \text {, and } 120 \mathrm{~min}\end{array}$ & $\begin{array}{c}\text { Relaxing SHR aortas in an endothelium- } \\
\text { independent manner } \\
\text { Reducing BP }\end{array}$ & {$[100]$} \\
\hline $\begin{array}{l}\text { Heliotropium } \\
\text { strigosum }\end{array}$ & Polyphenols & In vivo & Diabetic rabbits & 21 days & $\begin{array}{l}\text { Improving lipid profile (TC, TG, and } \\
\text { LDL-C } \downarrow \text { ) and lowering blood glucose }\end{array}$ & {$[25]$} \\
\hline $\begin{array}{l}\text { Mung bean } \\
\text { sprouts }\end{array}$ & NA & In vivo & $\mathrm{SD}$ rats & $1 \mathrm{~mL} / 200 \mathrm{~g} \mathrm{BW}, 8$ weeks & $\begin{array}{l}\text { Lowering BP and improving lipid } \\
\text { profile (LDL-C } \downarrow)\end{array}$ & {$[72]$} \\
\hline $\begin{array}{l}\text { Red dragon } \\
\text { fruit }\end{array}$ & NA & In vivo & $\mathrm{SD}$ rats & 4 weeks & $\begin{array}{l}\text { Improving lipid profile (TC, TG, and } \\
\text { LDL-C } \downarrow \text { ) and lowering blood glucose }\end{array}$ & {$[73]$} \\
\hline $\begin{array}{l}\text { Red dragon } \\
\text { fruit peel }\end{array}$ & NA & In vivo & $\begin{array}{l}\text { Hyperlipidemia } \\
\text { male mice }\end{array}$ & $\begin{array}{c}50,100,150, \text { and } \\
200 \mathrm{mg} / \mathrm{kg} \mathrm{BW}, 30 \text { days }\end{array}$ & $\begin{array}{c}\text { Improving lipid profile (TC, TG } \downarrow \text {, and } \\
\text { HDL-C } \uparrow)\end{array}$ & {$[74]$} \\
\hline $\begin{array}{l}\text { Citrus } \\
\text { maxima }\end{array}$ & NA & In vivo & Wistar rats & $\begin{array}{l}300 \text { and } 600 \mathrm{mg} / \mathrm{kg} \mathrm{BW}, \\
14 \text { days }\end{array}$ & $\begin{array}{c}\text { Improving lipid profile (TC, TG } \downarrow \text {, and } \\
\mathrm{HDL}-\mathrm{C} \uparrow \text { ), lowering blood glucose, and } \\
\text { increasing BW }\end{array}$ & [75] \\
\hline Bitter melon & $\beta$-Sitosterol & In vivo & $\begin{array}{l}\text { Hyperglycemia } \\
\text { rats }\end{array}$ & $71.1 \mathrm{mg}, 4$ weeks & $\begin{array}{l}\text { Improving lipid profile (TC, TG, } \\
\text { LDL-C, fecal cholesterol secretion, } \\
\text { cholesterol absorption } \downarrow \text {, and HDL-C } \uparrow \text { ) } \\
\text { and lowering blood glucose }\end{array}$ & [76] \\
\hline $\begin{array}{l}\text { Dried } \\
\text { chokeberry }\end{array}$ & Anthocyanins & In vivo & SHRs & $50 \mathrm{mg} / \mathrm{kg}$ and 4 weeks & $\begin{array}{c}\text { Ameliorating oxidative stress (TBARS } \downarrow \\
\text { and FRAP } \uparrow \text { ) and lowering SBP and } \\
\text { pulse pressure }\end{array}$ & [26] \\
\hline
\end{tabular}


TABle 2: Continued.

\begin{tabular}{|c|c|c|c|c|c|c|}
\hline Plants & Components & Study type & Subjects & Dose \& Time & Effects and mechanisms & Ref. \\
\hline Sweet cherry & Polyphenols & In vivo & Wistar rats & $\begin{array}{l}5 \% \text { and } 10 \%(w / w) \text { in } \\
\text { food (fruits); } 1 \% \text { and } 3 \% \\
(w / w) \text { in food (leaves), } \\
12 \text { weeks }\end{array}$ & $\begin{array}{c}\text { Decreasing BW gain, ameliorating } \\
\text { oxidative stress (SOD, GPx, CAT } \uparrow \text {, and } \\
\text { TBARS } \downarrow \text { ), and improving lipid profile } \\
\text { (LDL-C+VLDL-C } \downarrow \text { ) }\end{array}$ & {$[82]$} \\
\hline Wild rice & NA & In vivo & $\begin{array}{l}\text { Hyperlipidemic } \\
\text { rats }\end{array}$ & NA and 8 weeks & $\begin{array}{l}\text { Ameliorating oxidative stress (TAC, } \\
\text { SOD } \uparrow \text {, and MAD } \downarrow \text { ), improving lipid } \\
\text { profile (TG and TC } \downarrow \text { ), and mitigating } \\
\text { inflammation (CRP and TNF- } \alpha \downarrow \text { ) }\end{array}$ & {$[80]$} \\
\hline $\begin{array}{l}\text { Sambucus } \\
\text { nigra L. }\end{array}$ & Polyphenols & In vivo & Wistar rats & $0.046 \mathrm{~g} / \mathrm{kg} \mathrm{BW}, 8$ weeks & $\begin{array}{c}\text { Ameliorating oxidative stress (TAC } \uparrow \text { ), } \\
\text { lowering BP, and improving lipid profile } \\
\text { (HDL-C } \uparrow)\end{array}$ & {$[81]$} \\
\hline $\begin{array}{l}\text { Nepeta } \\
\text { deflersiana }\end{array}$ & NA & In vivo & Wistar rats & $\begin{array}{c}50 \text { and } 100 \mathrm{mg} / \mathrm{kg} \mathrm{BW} \text {, } \\
25 \text { days }\end{array}$ & $\begin{array}{l}\text { Attenuating myocardial injuries, } \\
\text { mitigating inflammation (TNF- } \alpha \text {, IL- } 6 \text {, } \\
\text { and IL-10 } \downarrow \text { ), and improving oxidative } \\
\text { stress (CAT, SOD, NO } \uparrow \text {, and MDA } \downarrow \text { ) }\end{array}$ & [29] \\
\hline Spinach & Nitrate & In vivo & $\begin{array}{l}\text { Swiss-Kunming } \\
\text { mice }\end{array}$ & $\begin{array}{c}15,30 \text {, and } 60 \mathrm{mg} / \mathrm{kg} \text { of } \\
\text { nitrate, } 28 \text { days }\end{array}$ & $\begin{array}{c}\text { Mitigating inflammation (CRP, TNF- } \alpha \text {, } \\
\text { and IL- } 6 \downarrow \text { ) and improving vascular } \\
\text { endothelial function (NO } \uparrow \text { and } \\
\text { endothelin- } 1 \downarrow \text { ), lipid profile (TC, TG, } \\
\text { LDL-C } \downarrow \text {, and HDL-C } \uparrow \text { ), and insulin } \\
\text { resistance }\end{array}$ & {$[88]$} \\
\hline $\begin{array}{l}\text { Zygophyllum } \\
\text { album roots }\end{array}$ & NA & In vivo & Wistar rats & 400 mg/kg BW, 60 days & $\begin{array}{c}\text { Attenuating myocardial injuries, } \\
\text { improving oxidative stress (MDA, PC } \downarrow \text {, } \\
\text { CAT, SOD, and GPx } \uparrow \text { ), and mitigating } \\
\text { inflammation (TNF- } \alpha \text {, IL- } 1 \beta \text {, IL- } 6 \text {, and } \\
\text { nuclear factor-kappa } \mathrm{B} \downarrow \text { ) }\end{array}$ & {$[84]$} \\
\hline $\begin{array}{l}\text { Spinacia } \\
\text { oleracea }\end{array}$ & Lutein & In vivo & Wistar rats & $\begin{array}{c}100,200 \text {, and } 300 \mathrm{mg} / \mathrm{kg} \\
\text { BW }\end{array}$ & 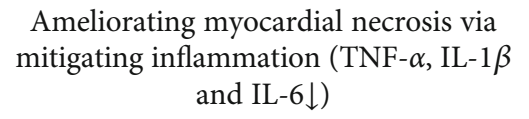 & [89] \\
\hline $\begin{array}{l}\text { Antidesma } \\
\text { bunius }\end{array}$ & NA & In vivo & SD rats & $\begin{array}{c}0.38,0.76 \text {, and } 1.52 \mathrm{~g} / \mathrm{kg} \text {, } \\
12 \text { weeks }\end{array}$ & $\begin{array}{l}\text { Improving oxidative stress (MDA } \downarrow \text { ) and } \\
\text { mitigating inflammation (TNF- } \alpha \text {, IL- } 6 \text {, } \\
\text { VCAM- } 1 \text {, and MCP- } 1 \downarrow)\end{array}$ & {$[90]$} \\
\hline Rice bran & Protein & In vivo & SD rats & $\begin{array}{c}250 \text { and } 500 \mathrm{mg} / \mathrm{kg}, 6 \\
\text { weeks }\end{array}$ & $\begin{array}{c}\text { Lowering } \mathrm{BP} \text { (ACE } \downarrow, \mathrm{NO} \text {, and } \mathrm{eNOS} \uparrow \text { ) } \\
\text { and reducing arterial stiffening, vascular } \\
\text { remodeling, and oxidative stress (SOD } \\
\text { and MDA } \downarrow \text { ) }\end{array}$ & {$[83]$} \\
\hline $\begin{array}{l}\text { Polygoni } \\
\text { multiflori } \\
\text { Radix }\end{array}$ & $\begin{array}{l}2,3,5,4^{\prime} \\
\text {-Tetrahydroxy- } \\
\text { stilbene-2-O- } \\
\text { beta-D-glucoside }\end{array}$ & In vivo & ApoE(-/-) mice & $1.125 \mathrm{mg} / \mathrm{g}, 8$ weeks & $\begin{array}{l}\text { Inhibiting atherosclerotic plaque } \\
\text { formation, improving lipid profile (TG } \\
\text { and ox-LDL } \downarrow \text { ), mitigating inflammation } \\
\text { (TNF- } \alpha \text {, IL-6, VCAM-1, and ICAM- } \\
1 \downarrow \text { ), and regulating gut microbiota } \\
\text { composition (Firmicutes/Bacteroidetes, } \\
\text { Akkermansia } \uparrow, \text { Proteobacteria, } \\
\text { Tenericutes, and Helicobacter pylori } \downarrow \text { ) }\end{array}$ & {$[28]$} \\
\hline Wasabi & $\begin{array}{c}\text { Allyl } \\
\text { isothiocyanate }\end{array}$ & In vivo & Wistar rats & $\begin{array}{c}5 \%(w / w) \text { in food, } 8 \\
\text { weeks }\end{array}$ & $\begin{array}{l}\text { Regulating gut microbiota composition } \\
\text { to prevent the development of } \\
\text { hypertension (Allobaculum, Sutterella, } \\
\text { Uncl. S247, Uncl. Coriobacteriaceae, and } \\
\text { Bifidobacterium } \uparrow)\end{array}$ & {$[93]$} \\
\hline $\begin{array}{l}\text { Lycium } \\
\text { ruthenicum } \\
\text { Murray }\end{array}$ & Anthocyanins & In vivo & C57BL/6 mice & $200 \mathrm{mg} / \mathrm{kg}, 12$ weeks & $\begin{array}{l}\text { Improving oxidative stress (TAC, SOD, } \\
\text { GPx } \uparrow \text {, and MDA } \downarrow \text { ) and inflammation } \\
\text { (TNF- } \alpha \text {, IL-6, and IL- } 1 \beta \downarrow \text { ), regulating } \\
\text { gut microbiota (Barnesiella, Alistipes, } \\
\text { Eisenbergiella, Coprobacter, and } \\
\text { Odoribacter } \uparrow \text { ), and increasing SCFA in } \\
\text { cecal and feces }\end{array}$ & {$[94]$} \\
\hline
\end{tabular}


TABLE 2: Continued.

\begin{tabular}{|c|c|c|c|c|c|c|}
\hline Plants & Components & Study type & Subjects & Dose \& Time & Effects and mechanisms & Ref. \\
\hline Tea & Polyphenols & In vivo & ApoE(-/-) mice & $\begin{array}{l}1.6,0.8 \text {, and } 0.4 \mathrm{~g} / \mathrm{L} \text { tea } \\
\text { polyphenols in drinking } \\
\text { water }\end{array}$ & $\begin{array}{l}\text { Lowering TC and LDL-C, decreasing } \\
\text { the plaque area/lumen area, and } \\
\text { promoting the proliferation of the } \\
\text { intestinal Bifidobacteria }\end{array}$ & {$[95]$} \\
\hline Berry mixture & Polyphenols & In vivo & $\begin{array}{l}\text { Dahl salt- } \\
\text { sensitive rats }\end{array}$ & $2 \mathrm{~g}, 9$ weeks & $\begin{array}{l}\text { Mitigating changes in the microbiota } \\
\text { composition caused by the high-salt diet } \\
\text { (phylum Bacteroidetes } \uparrow, \text { Firmicutes, and } \\
\text { Proteobacteria } \downarrow \text { ) }\end{array}$ & {$[96]$} \\
\hline
\end{tabular}

Note. NA: not available; SHRs: spontaneously hypertensive rats; SD rats: Sprague-Dawley rats; BW: body weight; $w / w$ : weight in weight; BP: blood pressure; SBP: systolic blood pressure; DBP: diastolic blood pressure; ACE: angiotensin-1 converting enzyme; NO: nitric oxide; eNOS: endothelial nitric oxide synthase; cGMP: cyclic guanosine monophosphate; TC: total cholesterol; TG: triglyceride; LDL-C: low-density lipoprotein cholesterol; HDL-C: high-density lipoprotein cholesterol; VLDL-C: very-low-density lipoprotein cholesterol; ox-LDL: oxidized low-density lipoprotein; TAC: total antioxidant capacity; FRAP: ferric ion-reducing antioxidant power; MDA: malondialdehyde; PC: protein carbonyls; TBARS: thiobarbituric acid reactive substances; SOD: superoxide dismutase; GPx: glutathione peroxidase; GR: glutathione reductase; CAT: catalase; TNF- $\alpha$ : tumor necrosis factor $\alpha$; CRP: C reactive protein; IL-1 $\beta$ : interleukin-1 $\beta$; IL-6: interleukin-6; IL-10: interleukin-10: VCAM-1: vascular cell adhesion molecule 1; ICAM-1: intercellular adhesion molecule 1; MCP-1: monocyte chemotactic protein 1; SCFA: short-chain fatty acids.

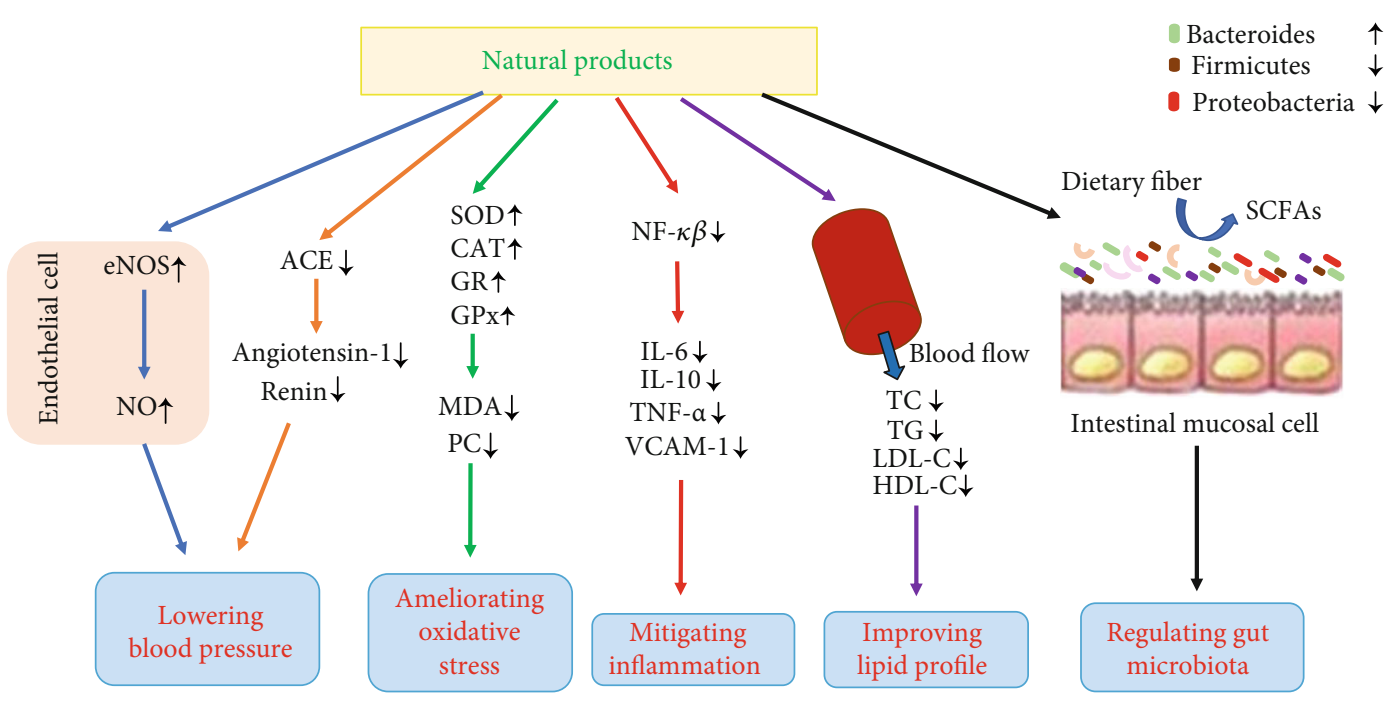

FIGURE 1: The mechanisms of natural products against cardiovascular diseases. Natural products could stimulate the activity of endothelial nitric oxide synthase (eNOS) and promote the release of nitric oxide (NO) to lower blood pressure; they can also inhibit the activity of angiotensin-1 converting enzyme (ACE) and decrease angiotensin-1 and renin to lower blood pressure. Natural products could promote the activities of antioxidant enzymes, like superoxide dismutase (SOD), catalase (CAT), glutathione reductase (GR), and glutathione peroxidase $(\mathrm{GPx})$, and decrease the concentration of peroxidative products, like malondialdehyde (MDA) and protein carbonyls (PC), to ameliorate oxidative stress. Through the nuclear factor-kappa B (NF- $\kappa \beta$ ) signaling pathway, natural products could decrease levels of inflammatory markers, like tumor necrosis factor- $\alpha$ (TNF- $\alpha$ ), interleukin-6 (IL-6), interleukin-10 (IL-10), and vascular cell adhesion molecule-1 (VCAM-1), to mitigate inflammation. Natural products could decrease the levels of total cholesterol (TC), triglyceride (TG), and low-density lipid protein cholesterol (LDL-C) and increase the level of high-density lipid protein cholesterol (HDL-C) to improve lipid profile. Natural products could increase the abundance of beneficial bacteria, like Bacteroides, and decrease the abundance of harmful bacteria, like Firmicutes and Proteobacteria, to regulate gut microbiota.

blood lipid-lowering efficacy. Furthermore, after administration with Citrus maxima juice for 14 days, male Wistar rats showed a significant decrease of TC and TG, along with an increase of HDL-C [75]. Furthermore, feeding with fresh bitter melon fruit juice for 4 weeks markedly dropped down the levels of blood glucose, TG, TC, and LDL-C in hyperglycemia rats compared with the initial levels, but the HDL-C level was dramatically elevated. Meanwhile, bitter melon effectively improved the fecal cholesterol secretion and suppressed cholesterol absorption, posing a potent ability to improve lipid profile [76].
3.3. Ameliorating Oxidative Stress. Oxidative stress, a major cause of the CVDs, is the result of the reduction of antioxidant capacity and the production of excessive reactive oxygen species (ROS) [77-79]. Some natural products could improve oxidative stress via promoting the activities of antioxidant enzymes, like superoxide dismutase (SOD), catalase (CAT), glutathione reductase (GR), and glutathione peroxidase (GPx) and decreasing the concentration of peroxidative products, like malondialdehyde (MDA) and protein carbonyls, hence promising to prevent and treat CVDs. A study showed that the intake of North American or Chinese wild 
rice effectively inhibited the formation of oxidative stress in hyperlipidemic rats via improving total antioxidant capacity, increasing SOD activity, and reducing MDA concentration. In addition, two wild rice varieties were also effective in suppressing hyperlipidemia and inflammation in rats [80]. Moreover, the polyphenol extract of Sambucus nigra L. ameliorated oxidative stress by enhancing total antioxidant capacity, and reduced both SBP and DBP in Wistar rats. Its combination with a renin inhibitor (Aliskiren) generated a superior antioxidant effect compared to administering the two separately, and it could also reduce the side effects of the antihypertensive agent [81]. Furthermore, the effects of dried chokeberry fruit extract on haemodynamic parameters, lipid profile, and oxidative stress were evaluated in spontaneously hypertensive rats, and anthocyanins, phenolic acids, and flavonoids in the extract were determined by the HPLC/DAD method. The extract rich in anthocyanins significantly reduced systolic and pulse pressures via increased diuresis. The thiobarbituric acid reactive substances (TBARS) in plasma and erythrocytes were significantly decreased in the treated group. The consumption of the extract also reduced lipid peroxidation through improving the ferric ion-reducing antioxidant power (FRAP) of plasma, but the activity of SOD in the treated group was significantly lower compared to the control group [26]. Additionally, the supplement of sweet cherry fruit and leaves to the high-fat-high-cholesterol diet in Wistar rats decreased body gain, improved liver function, and reduced inflammation and oxidative stress (by provoking the activities of SOD, GPx, GR, and CAT, and reducing the level of TBARS). The fruit and leaves reduced lipid accumulation in the liver and improved the lipid profile in serum. These effects could be from the regulation of the expression of fatty acid synthesis and oxidation-related genes [82]. In a previous study, the effects of rice bran protein hydrolysate on arterial stiffening, vascular remodeling, and oxidative stress were evaluated in rats fed a high-carbohydrate and highfat diet. The hydrolysate supplementation significantly alleviated hyperglycemia, insulin resistance, dyslipidemia, hypertension, increased aortic pulse wave velocity, aortic wall hypertrophy, and vascular remodeling. The hydrolysate reduced the levels of ACE and tumor necrosis factor-alpha in plasma. The hydrolysate also alleviated oxidative stress by decreasing plasma MDA, reducing superoxide production, and suppressing p47 (phox) NADPH oxidase expression in the vascular tissues. The hydrolysate increased plasma nitrate/nitrite level and upregulated eNOS expression in the aortas of model group rats, indicating that the hydrolysate increased NO production [83]. In another study, Zygophyllum album root extract was analyzed using HPLC-DAD-ESI-QTOFMS/MS, and twenty-six molecules were identified, including phenolic compounds and saponins. The extract significantly improved the heart injury markers, lipid peroxidation, protein oxidation, antioxidant capacity (SOD, CAT, and GPx), and DNA structure. The extract reduced the expressions of NFkappa $\mathrm{B}$, decreased plasmatic proinflammatory cytokine concentration, and suppressed the myocardial collagen deposition [84]. An in vivo study showed that apple polyphenol extract possessed a positive effect on vascular oxidative stress and endothelium function [85].
3.4. Mitigating Inflammation. Inflammatory response is a prominent pathological change in the development of CVDs, which can be characterized by increased levels of inflammatory markers, like tumor necrosis factor- $\alpha$ (TNF- $\alpha$ ), interleukin- 6 (IL-6), interleukin-10 (IL-10), C reactive protein (CRP), monocyte chemoattractant protein-1 (MCP-1), and vascular cell adhesion molecule-1 (VCAM-1) [86, 87]. It has been reported that some natural products were able to downregulate the expression of these cytokines and mitigate inflammation, which was a way of lowering the risk of CVDs. For example, an in vivo study pointed out that Nepeta deflersiana ethanolic extract effectively attenuated the myocardial injuries in Wistar rats by improving oxidative stress, inhibiting apoptosis, and mitigating inflammation. Nepeta deflersiana exerted an antiinflammatory effect via the downregulation of the gene expression of TNF- $\alpha$, IL-6, and IL-10 [29]. Another study found that the oral administration of Zygophyllum album root extract ameliorated the myocardial injuries in Wistar rats though the improvement of oxidative stress and the alleviation of inflammation. Zygophyllum album root extract decreased the plasma concentration of proinflammatory cytokines, like TNF- $\alpha$, IL$1 \beta$, and IL-6 [84]. Additionally, spinach nitrate significantly lowered the elevated levels of serum CRP, TNF- $\alpha$, and IL- 6 induced by a high-fat and high-fructose diet in male mice, showing a strong anti-inflammatory capacity [88]. Also, a study demonstrated that Spinacia oleracea leaf methanolic extract dose-dependently attenuated isoproterenol-induced myocardial necrosis in male Wistar rats via mitigating the levels of proinflammatory cytokines, such as TNF- $\alpha$, IL- $1 \beta$, and IL-6 [89]. Moreover, Antidesma bunius extract significantly ameliorated the expressions of genes involved with proinflammatory cytokines, such as TNF- $\alpha$, IL-6, VCAM-1, and MCP-1, showing great anti-inflammatory capacity [90].

3.5. Regulating Gut Microbiota. Recent interest has focused on the impact of gut microbiota on chronic diseases, especially CVDs. Increasing evidence has shown that gut microbiota was closely associated with the function of the cardiovascular system via contributing to the fermentation of dietary fiber in the colon, the production of short-chain fatty acids (SCFA), and the intestinal absorption of phytochemicals $[91,92]$. Hence, it is of great significance to maintain the balance of intestinal flora to protect against CVDs. Some studies revealed that several natural products could regulate the homeostasis of gut microbiota. For example, a study demonstrated that wasabi powder prevented the development of hypertension in Wistar rats via changing the composition of gut microbiota, increasing the abundance of Allobaculum, Sutterella, Uncl. S247, Uncl. Coriobacteriaceae, and Bifidobacterium [93]. Moreover, treatment with anthocyanins extracted from Lycium ruthenicum Murray could not only improve oxidative stress and inflammation in C57BL/6 mice but also promote the proliferation of Barnesiella, Alistipes, Eisenbergiella, Coprobacter, and Odoribacter and increase the production of SCFA in cecal and feces [94]. Additionally, a study found that except for the improvement of lipid profile and inflammation, Polygoni multiflori Radix extract significantly inhibited atherosclerosis plaque formation in $\operatorname{ApoE}(-/-)$ mice via regulating gut microbiota 
composition [28]. Also, a study pointed out that tea polyphenols dose-dependently increased the abundance of intestinal Bifidobacteria in high-fat diet-fed ApoE(-/-) mice, and this increase negatively correlated with plaque area/lumen area ratios, suggesting that tea polyphenols could reduce atherosclerosis plaque induced by high-fat diet via increasing intestinal Bifidobacteria [95]. Furthermore, the intake of berry mixture, including blueberries, blackberries, raspberries, Portuguese crowberry, and strawberry tree fruit, increased the abundance of phylum Bacteroidetes, decreased the abundance of Firmicutes, and reduced the elevated abundance of Proteobacteria induced by a high-salt diet in Dahl salt-sensitive rats [96].

In brief, based on the in vitro and in vivo experimental studies, we summarized the potential mechanisms of some natural products protecting against CVDs, including reducing blood pressure, improving the lipid profile, ameliorating oxidative stress, mitigating inflammation, and regulating gut microbiota.

\section{Clinical Trials}

The benefits of reducing the risk of CVD events through the consumption of antioxidant natural products and their active ingredients have been studied in multiple clinical trials. Here, we summarize the protective effects of some natural products on CVDs (Table 3).

4.1. The Effects of Fruits on CVDs. Several clinical trials revealed the inverse relationship between the consumption of fruits and risk of CVDs. A randomized controlled trial (RCT) found that guava pulp significantly improved lipid profile by decreasing the levels of TC, TG, and LDL-C and increasing the level of HDL-C [101]. Another RCT pointed out that intake of $100 \mathrm{~g}$ soursop fruit twice per day for 3 months markedly decreased the levels of SBP, DBP, and serum uric acid in prehypertensive participants compared to the control group [102]. Additionally, a controlled nonrandomized clinical study showed that consuming $300 \mathrm{~mL}$ of orange juice for 2 months improved LDL-C, blood glucose, insulin sensitivity, and gut microbiota metabolism in healthy women [103]. Furthermore, a cross-over study found that after the intervention of 200 or $400 \mathrm{mg}$ anthocyanin from haskap berry, the blood pressure levels in participants aged 62-81 years were significantly reduced [104]. Hence, consuming some fruits, like guava, soursop, and orange, is an effective way to prevent and manage CVDs.

4.2. The Effects of Vegetables on CVDs. Some vegetables also showed a protective effect on CVDs. An RCT found that the intake of $213 \mathrm{mg}$ tomato extract for 4 weeks lowered DBP and mean arterial pressure in patients with hypertension and high risk of CVDs [105]. Moreover, several studies revealed the potent hypotensive efficacy of beetroot which was associated with its high content of nitrate. For example, a study demonstrated that consuming $70 \mathrm{~mL}$ beetroot juice significantly lowered the level of DBP in hypertensive pregnant women [106]. Additionally, daily consumption of $1.2 \mathrm{~g}$ eggplant powder markedly improved blood pressure and the psychological state of stressed participants with normalhigh blood pressure or stage 1 hypertension [107]. Therefore, it is advisable to increase the intake of tomato, beetroot, and eggplant to protect the health of the cardiovascular system.

4.3. The Effects of Spices on CVDs. Similarly, some spices effectively reduced the risk of CVDs. An RCT showed that after intervention with $3 \mathrm{~g}$ cardamom for 2 months, the levels of TC and LDL-C in overweight and obese prediabetic women were remarkably lowered, while SBP, DBP, glycemic indices, and serum lipid values in the cardamom group did not significantly differ from the placebo group [108]. Another study compared the cardiovascular-protective effect of cardamom, cinnamon, saffron, and ginger, demonstrating that all of them showed potent abilities in controlling blood pressure and improving endothelial function [33]. Besides, daily ingestion of Satureja hortensis L. effectively improved the lipid profile in patients with metabolic syndrome by lowering TC, TG, and LDL-C and increasing HDL-C [109]. Moreover, garlic and cumin showed a strong hypotensive effect on patients with type 2 diabetes [110]. In brief, some spices, like cardamom, cinnamon, saffron, ginger, garlic, and cumin, hold great promise in preventing and treating CVDs.

4.4. The Effects of Nuts on CVDs. Nuts contain several antioxidant components and possess many bioactivities [111-113]. Moderate intake of nuts also attenuated the risk factors of CVDs. An RCT found that consumption of almond which provided $15 \%$ energy significantly lowered truncal and total body fat as well as DBP in overweight or obese adults [114]. Another 6-month-long RCT demonstrated that intake of walnut remarkably reduced body weight, body mass index, waist circumference, SBP, TC, and LDL-C [115]. Moreover, supplementing type 2 diabetes participants with cashew nut considerably reduced SBP and increased HDL-C, while significant differences were not observed in body weight, body mass index, glycemic, and other lipid variables [116]. Additionally, intake of mixed nuts, including almonds, cashews, hazelnuts, pecans, Brazil nuts, macadamia nuts, pistachios, walnuts, and peanuts, could attenuate CVD risk factors by improving body weight and glucose regulation, without exerting the negative effects on lipids compared with a common carbohydrate-rich snack [117].

4.5. The Effects of Teas on CVDs. As the second-most consumed beverage worldwide, the nutrition value of teas is extensively investigated. Several studies found that the consumption of teas could ameliorate the risk factors of CVDs. For example, supplementation with green tea extract, which contained 1,315 mg catechins, could significantly improve lipid profile in postmenopausal women by reducing the levels of TC, LDL-C, and non-HDL-C [118]. Furthermore, a study pointed out that the consumption of phytosterol-enriched functional black tea could lower TC, LDL-C, and apolipoprotein B in mild hypercholesterolemia subjects, accompanied with the amelioration of oxidative stress [119]. Moreover, an open-label pilot study found that after daily administration of $2 \mathrm{~g} / \mathrm{L}$ kosen-cha, obese subjects showed a significant 
TABLE 3: The effects of antioxidant natural products on CVDs from clinical studies.

\begin{tabular}{|c|c|c|c|c|c|c|}
\hline Plant types & Components & Study type & Subjects & Dose and time & Outcomes & Ref. \\
\hline \multicolumn{7}{|l|}{ Fruits } \\
\hline Guava & NA & RCT & 45 healthy students & 400 g/day, 6 weeks & $\begin{array}{l}\text { Lowering BP, TC, TG, and } \\
\text { LDL-C }\end{array}$ & [101] \\
\hline Soursop & NA & RCT & $\begin{array}{l}143 \text { hypertensive } \\
\text { subjects }\end{array}$ & $2 \times 100$ g/day, 3 months & Lowering BP & {$[102]$} \\
\hline Orange juice & $\begin{array}{l}\text { Hesperidin } \\
\text { and naringin }\end{array}$ & $\begin{array}{l}\text { Controlled } \\
\text { nonrandomized } \\
\text { clinical study }\end{array}$ & 10 healthy women & $300 \mathrm{~mL} /$ day, 2 months & $\begin{array}{l}\text { Improving LDL-C, blood } \\
\text { glucose, insulin sensitivity, } \\
\text { and gut microbiota } \\
\text { metabolism }\end{array}$ & [103] \\
\hline Haskap berry & Anthocyanin & Cross-over study & $\begin{array}{c}20 \text { adults aged } 62-81 \\
\text { years }\end{array}$ & $400 \mathrm{mg}$ anthocyanins & $\begin{array}{c}\text { Lowering BP and improving } \\
\text { episodic memory }\end{array}$ & [104] \\
\hline Cherry juice & Anthocyanin & $\begin{array}{l}\text { Pilot cross-over } \\
\text { study }\end{array}$ & $\begin{array}{l}6 \text { young and } 7 \text { old } \\
\text { adults }\end{array}$ & $\begin{array}{c}300 \mathrm{~mL} \text { or } 100 \mathrm{~mL}, 3 \\
\text { times }\end{array}$ & Lowering $\mathrm{BP}$ and heart rate & [126] \\
\hline $\begin{array}{l}\text { Pomegranate } \\
\text { extract }\end{array}$ & Polyphenols & RCT & $\begin{array}{l}55 \text { subjects without } \\
\text { any symptomatic } \\
\text { disease }\end{array}$ & $\begin{array}{l}\text { Containing } 210 \mathrm{mg} \\
\text { punicalagins, } 328 \mathrm{mg} \\
\text { other pomegranate } \\
\text { polyphenols, and } 0-37 \mathrm{mg} \\
\text { anthocyanins, } 8 \text { weeks }\end{array}$ & Lowering SBP & [127] \\
\hline Plum juice & Anthocyanins & $\begin{array}{l}\text { Pilot cross-over } \\
\text { dose-timing } \\
\text { study }\end{array}$ & $\begin{array}{l}12 \text { older }(65+\text { years }) \\
\text { and } 12 \text { younger } \\
(18-45 \text { years }) \text { adults }\end{array}$ & $\begin{array}{l}300 \mathrm{~mL} \text { or } 100 \mathrm{~mL}, 3 \\
\text { times }\end{array}$ & $\begin{array}{l}\text { Reducing BP and } \\
\text { cardiovascular responses }\end{array}$ & [128] \\
\hline $\begin{array}{l}\text { Noni and } \\
\text { chokeberry } \\
\text { juices }\end{array}$ & NA & RCT & 88 young adults & $\begin{array}{c}\text { Noni juice } 30 \mathrm{~mL} \\
\text { chokeberry juice } 200 \mathrm{~mL}\end{array}$ & $\begin{array}{l}\text { Lowering SBP, DBP, heart } \\
\text { rate, and blood glucose (noni } \\
\text { juice) } \\
\text { Slightly lowering DBP } \\
\text { (chokeberry juice) }\end{array}$ & [129] \\
\hline \multicolumn{7}{|l|}{ Vegetables } \\
\hline $\begin{array}{l}\text { Tomato } \\
\text { extract }\end{array}$ & NA & RCT & $\begin{array}{l}65 \text { patients with } \\
\text { hypertension and a } \\
\text { high risk of CVD }\end{array}$ & $213 \mathrm{mg} /$ day, 4 weeks & $\begin{array}{l}\text { Lowering DBP and mean } \\
\text { arterial pressure }\end{array}$ & [105] \\
\hline Beetroot juice & Nitrate & $\begin{array}{l}\text { Open-label cross- } \\
\text { over study }\end{array}$ & $\begin{array}{l}17 \text { patients with } \\
\text { chronic kidney } \\
\text { disease }\end{array}$ & $\begin{array}{l}\text { Containing } 300 \mathrm{mg} \\
\text { nitrate, } 4 \text { hours }\end{array}$ & $\begin{array}{l}\text { Lowering peripheral } \mathrm{BP} \text { and } \\
\text { mean arterial pressure }\end{array}$ & [130] \\
\hline Beetroot juice & Nitrate & $\begin{array}{l}\text { Double-blind } \\
\text { cross-over study }\end{array}$ & $\begin{array}{l}20 \text { subjects with } \\
\text { treated yet } \\
\text { uncontrolled } \\
\text { hypertension }\end{array}$ & $\begin{array}{l}\text { Containing } 12.9 \mathrm{mmol} \\
\text { nitrate, } 7 \text { days }\end{array}$ & $\begin{array}{l}\text { Increasing plasma nitrite and } \\
\text { reducing } \mathrm{BP}\end{array}$ & [131] \\
\hline Beetroot juice & Nitrate & Feasibility trial & $\begin{array}{l}40 \text { hypertensive } \\
\text { pregnant women }\end{array}$ & $70 \mathrm{~mL} /$ day, 8 days & Lowering DBP & [106] \\
\hline $\begin{array}{l}\text { Sateria } \\
\text { palmifolia }\end{array}$ & NA & Quasiexperiment & 10 pregnant women & NA & Lowering BP & [132] \\
\hline $\begin{array}{l}\text { Eggplant } \\
\text { powder }\end{array}$ & NA & RCT & $\begin{array}{c}100 \text { stressed } \\
\text { participants with } \\
\text { normal-high BP or } \\
\text { stage } 1 \text { hypertension }\end{array}$ & $1.2 \mathrm{~g} / \mathrm{day}, 12$ weeks & $\begin{array}{l}\text { Improving BP and } \\
\text { psychological state }\end{array}$ & [107] \\
\hline $\begin{array}{l}\text { Beetroot, } \\
\text { rocket salad } \\
\text { and spinach }\end{array}$ & Nitrate & $\begin{array}{l}\text { Semirandomized } \\
\text { cross-over study }\end{array}$ & 11 men and 7 women & $\begin{array}{l}\text { Each group containing } \\
800 \mathrm{mg} \text { nitrate }\end{array}$ & Lowering BP & [133] \\
\hline \multicolumn{7}{|l|}{ Spices } \\
\hline $\begin{array}{l}\text { Satureja } \\
\text { hortensis L. }\end{array}$ & NA & RCT & $\begin{array}{l}47 \text { patients with } \\
\text { metabolic syndrome }\end{array}$ & $450 \mathrm{mg} /$ day, 10 weeks & $\begin{array}{l}\text { Lowering TC, TG, and LDL- } \\
\mathrm{C} \text { and increasing HDL-C }\end{array}$ & [109] \\
\hline Cardamom & NA & RCT & $\begin{array}{l}80 \text { overweight and } \\
\text { obese prediabetic } \\
\text { women }\end{array}$ & $3 \mathrm{~g}, 2$ months & Lowering TC and LDL-C & [108] \\
\hline
\end{tabular}


TABle 3: Continued.

\begin{tabular}{|c|c|c|c|c|c|c|}
\hline Plant types & Components & Study type & Subjects & Dose and time & Outcomes & Ref. \\
\hline $\begin{array}{l}\text { Garlic and } \\
\text { cumin }\end{array}$ & NA & RCT & $\begin{array}{l}75 \text { patients with } \\
\text { T2DM }\end{array}$ & $\begin{array}{c}\text { Garlic powder: } \\
300 \mathrm{mg} / \text { three times a day; } \\
\text { cumin extract: } \\
100 \mathrm{mg} / \text { twice a day, } 2 \\
\text { months }\end{array}$ & Lowering BP & [110] \\
\hline $\begin{array}{l}\text { Cinnamon, } \\
\text { cardamom, } \\
\text { saffron, and } \\
\text { ginger }\end{array}$ & NA & RCT & $\begin{array}{l}204 \text { patients with } \\
\text { T2DM }\end{array}$ & $\begin{array}{c}3 \mathrm{~g} \text { cinnamon, } 3 \mathrm{~g} \\
\text { cardamom, } 1 \mathrm{~g} \text { saffron, } \\
\text { and } 3 \mathrm{~g} \text { ginger in a glass of } \\
\text { black tea, respectively, } 8 \\
\text { weeks }\end{array}$ & $\begin{array}{l}\text { All showed potent effects on } \\
\text { controlling BP and improving } \\
\text { endothelial function }\end{array}$ & {$[33]$} \\
\hline \multicolumn{7}{|l|}{ Nuts } \\
\hline Almond & NA & RCT & $\begin{array}{l}86 \text { overweight or } \\
\text { obese adults }\end{array}$ & $\begin{array}{l}15 \% \text { energy from almond, } \\
12 \text { weeks }\end{array}$ & $\begin{array}{l}\text { Lowering truncal and total } \\
\text { body fat as well as DBP }\end{array}$ & [114] \\
\hline Walnuts & NA & RCT & 211 participants & $30 \mathrm{~g} /$ day, 3 months & Lowering BP & [134] \\
\hline Walnuts & NA & RCT & $\begin{array}{l}100 \text { overweight and } \\
\text { obese participants }\end{array}$ & $\begin{array}{l}\text { 15\% energy from walnut, } \\
6 \text { months }\end{array}$ & $\begin{array}{c}\text { Reducing BW, BMI, waist } \\
\text { circumference, SBP, TC, and } \\
\text { LDL-C }\end{array}$ & [115] \\
\hline Walnuts & $\begin{array}{l}\alpha \text {-Linolenic } \\
\text { acid }\end{array}$ & RCT & $\begin{array}{l}42 \text { adults at } \\
\text { cardiovascular risk }\end{array}$ & $57-99 \mathrm{~g} /$ day, 6 weeks & Regulating gut microbiota & [135] \\
\hline Cashew nut & NA & RCT & $\begin{array}{l}300 \text { Asian Indians } \\
\text { with T2DM }\end{array}$ & $30 \mathrm{~g} /$ day, 12 weeks & $\begin{array}{l}\text { Decreasing SBP and } \\
\text { increasing HDL-C }\end{array}$ & [116] \\
\hline Cashew nut & NA & RCT & 42 adults & $42 \mathrm{~g} /$ day, 4 weeks & $\begin{array}{l}\text { No effect on risk factors of } \\
\text { CVD }\end{array}$ & [136] \\
\hline Mixed nuts & NA & RCT & $\begin{array}{l}48 \text { overweight and } \\
\text { obese adults }\end{array}$ & $250 \mathrm{kcal}, 4$ and 8 weeks & $\begin{array}{l}\text { Improving } \mathrm{BW} \text { and glucose } \\
\text { regulation }\end{array}$ & [117] \\
\hline \multicolumn{7}{|l|}{ Teas } \\
\hline Green tea & Catechin & RCT & $\begin{array}{c}1,075 \\
\text { postmenopausal } \\
\text { women }\end{array}$ & $\begin{array}{c}\text { Containing } 1,315 \mathrm{mg} \\
\text { catechins, } 6 \text { and } 12 \\
\text { months }\end{array}$ & $\begin{array}{l}\text { Lowering TC, LDL-C, and } \\
\text { non-HDL-C }\end{array}$ & [118] \\
\hline Kosen-cha & Catechin & $\begin{array}{l}\text { Open-label pilot } \\
\text { study }\end{array}$ & 6 obese subjects & $5 \mathrm{~g} / \mathrm{L}, 12$ weeks & $\begin{array}{l}\text { Lowering BW, BMI, waist } \\
\text { circumferences, and serum } \\
\text { TG levels and improving } \\
\text { insulin resistance, vascular } \\
\text { function, and cardiac } \\
\text { hypertrophy }\end{array}$ & [120] \\
\hline Goishi tea & Polyphenols & RCT & 77 subjects & $\begin{array}{l}\text { Containing } 122 \mathrm{mg} \text { of } \\
\text { polyphenols, } 12 \text { weeks }\end{array}$ & $\begin{array}{c}\text { Increasing HDL-C and } \\
\text { lowering TG }\end{array}$ & [137] \\
\hline Black tea & Phytosterol & RCT & $\begin{array}{c}\text { Subjects with mild } \\
\text { hypercholesterolemia }\end{array}$ & $\begin{array}{l}\text { Phytosterol-enriched } \\
\text { functional black tea, } 4 \\
\text { weeks }\end{array}$ & $\begin{array}{l}\text { Lowering TC, LDL-C, and } \\
\text { apolipoprotein B and } \\
\text { improving oxidative stress }\end{array}$ & [119] \\
\hline \multicolumn{7}{|l|}{ Others } \\
\hline $\begin{array}{l}\text { Hibiscus } \\
\text { sabdariffa }\end{array}$ & NA & Cross-over study & $\begin{array}{l}25 \text { men with } 1 \% \text { to } \\
10 \% \text { CVD risk }\end{array}$ & $250 \mathrm{~mL}, 0,2$, and $4 \mathrm{~h}$ & $\begin{array}{c}\text { Reducing endothelial } \\
\text { dysfunction and CVD risk }\end{array}$ & [138] \\
\hline $\begin{array}{l}\text { Hibiscus } \\
\text { sabdariffa }\end{array}$ & NA & RCT & $\begin{array}{l}46 \text { patients with stage } \\
1 \text { hypertension }\end{array}$ & 2 cup/morning, 1 month & Reducing BP & [123] \\
\hline Chamomile & NA & RCT & 50 diabetic patients & $200 \mathrm{~mL} /$ day, 4 weeks & $\begin{array}{l}\text { Lowering TC, LDL-C, and } \\
\text { creatinine }\end{array}$ & [139] \\
\hline \multirow[t]{2}{*}{ Soy flour } & NA & $\begin{array}{l}3 \times 3 \text { completely } \\
\text { randomized } \\
\text { repeated study }\end{array}$ & $\begin{array}{l}75 \text { postmenopausal } \\
\text { women with } \\
\text { prediabetes and } \\
\text { prehypertension }\end{array}$ & 25 and $45 \mathrm{~g} /$ day, 12 weeks & $\begin{array}{l}\text { Lowering fasting plasma } \\
\text { glucose, fasting insulin, } \\
\text { insulin resistance, and DBP }\end{array}$ & [124] \\
\hline & NA & Pilot RCT & & & & [140] \\
\hline
\end{tabular}


TABLE 3: Continued.

\begin{tabular}{|c|c|c|c|c|c|c|}
\hline Plant types & Components & Study type & Subjects & Dose and time & Outcomes & Ref. \\
\hline $\begin{array}{l}\text { Navy beans } \\
\text { and rice bran }\end{array}$ & & & $\begin{array}{l}38 \text { children with } \\
\text { abnormal cholesterol }\end{array}$ & $\begin{array}{l}17.5 \mathrm{~g} / \text { day cooked navy } \\
\text { bean powder; } 15 \mathrm{~g} / \text { day } \\
\text { heat-stabilized rice bran; } \\
9 \mathrm{~g} / \text { day navy beans and } \\
8 \mathrm{~g} / \text { day rice bran, } 4 \text { weeks }\end{array}$ & $\begin{array}{l}\text { Modulating the plasma } \\
\text { metabolome and reducing } \\
\text { CVD risk }\end{array}$ & \\
\hline Oat noodles & NA & RCT & $\begin{array}{c}84 \text { healthy and mild } \\
\text { hypercholesterolemic } \\
\text { subjects }\end{array}$ & $\begin{array}{c}100 \mathrm{~g} / \text { day (replacing } 1 \text { or } \\
2 \text { meals of staple food), } 10 \\
\text { weeks }\end{array}$ & $\begin{array}{c}\text { Reducing TC/HDL-C and } \\
\text { LDL-C/HDL-C ratios and } \\
\text { blood pressure }\end{array}$ & {$[125]$} \\
\hline $\begin{array}{l}\text { Green coffee } \\
\text { bean }\end{array}$ & NA & RCT & $\begin{array}{l}\text { Patients with the } \\
\text { metabolic syndrome }\end{array}$ & $400 \mathrm{mg}$ twice/day, 8 weeks & $\begin{array}{l}\text { Reducing SBP, insulin } \\
\text { resistance, and abdominal } \\
\text { obesity and inhibiting } \\
\text { appetite }\end{array}$ & {$[141]$} \\
\hline
\end{tabular}

Note. NA: not available; RCT: randomized controlled trial; CVD: cardiovascular disease; T2DM: type 2 diabetes mellitus; BW: body weight; BMI: body mass index; BP: blood pressure; SBP: systolic blood pressure; DBP: diastolic blood pressure; TC: total cholesterol; TG: triglyceride; LDL-C: low-density lipoprotein cholesterol; HDL-C: high-density lipoprotein cholesterol.

reduction of body weight, BMI, waist circumferences, and serum TG levels, as well as the improvement of insulin resistance, vascular function, and cardiac hypertrophy [120].

4.6. The Effects of Other Plants on CVDs. Other natural products also possessed the ability to protect the health of the cardiovascular system, such as cereals, legumes, and herbs [121, 122]. For example, drinking 2 cups of Hibiscus sabdariffa in the morning effectively reduced blood pressure in patients with stage 1 hypertension [123]. Besides, a $3 \times 3$ completely randomized repeated study showed that daily consumption of $25 \mathrm{~g}$ or $45 \mathrm{~g}$ soy flour markedly lowered the levels of fasting plasma glucose, fasting insulin, insulin resistance, and DBP in postmenopausal women with prediabetes and prehypertension [124]. Additionally, using oat noodles to replace 1 or 2 meals of staple food could reduce blood pressure, and improve lipid profile by lowering TC/HDL-C and LDL$\mathrm{C} / \mathrm{HDL}-\mathrm{C}$ ratios [125]. Hence, supplementing the consumption of Hibiscus sabdariffa, soy, and oat helps to reduce the risk of CVDs.

In short, clinical trials involving different conditions of subjects illustrated that some antioxidant natural products could improve cardiovascular health and reduce the risk of CVDs, which might be related to decreasing blood pressure, regulating serum lipids, lowering blood glucose, and lowering body weight.

\section{Conclusions}

As a public health problem of global concern, CVDs have attracted considerable attention. Some antioxidant natural products have been proven capable of preventing CVDs. Multiple epidemiological investigations enrolling participants from different countries, different ages, and so on, suggested that the consumption of antioxidant natural products was beneficial to reduce the risk of CVD events. Moreover, results from experimental studies showed that some natural products exerted cardiovascular-protective effects via different mechanisms of action, such as reducing blood pressure, improving the lipid profile, ameliorating oxidative stress, mitigating inflammation, and regulating gut microbiota. Furthermore, clinical trials confirmed that some antioxidant natural products could prevent and treat CVDs. Supported by current evidence, some antioxidant natural products and their active compounds could be developed into functional foods or medicine for the prevention and treatment of CVDs. In the future, the effects of more antioxidant natural products on CVDs should be evaluated to find out more cardiovascularprotective natural products, and relative bioactive components should be isolated and identified. In addition, the mechanisms of action should be elucidated further. Furthermore, special attention should be paid to the safety of relative natural products and functional foods.

\section{Conflicts of Interest}

The authors declare that there is no conflict of interest regarding the publication of this article.

\section{Authors' Contributions}

D.-D.Z., R.-Y.G., and H.-B.L. conceptualized this study. D.D.Z., M.L., A.S., Q.-Q.M., and B.-Y.L. wrote the original draft of this manuscript. R.-Y.G. and H.-B.L. wrote the manuscript and contributed in reviewing and editing. R.-Y.G. and H.B.L. supervised the study. R.-Y.G. and H.-B.L. contributed in funding acquisition.

\section{Acknowledgments}

We thank Hang-Yu Li for the support given to this study. This study was supported by the National Key R\&D Program of China (No. 2018YFC1604405), the China Central PublicInterest Scientific Institution Basal Research Fund (No. Y2020XK05), and the Key Project of Guangdong Provincial Science and Technology Program (No. 2014B020205002).

\section{References}

[1] H. D. Wang, M. Naghavi, C. Allen et al., "Global, regional, and national life expectancy, all-cause mortality, and causespecific mortality for 249 causes of death, 1980-2015: a systematic analysis for the global burden of disease study 2015," Lancet, vol. 388, pp. 1459-1544, 2016. 
[2] M. Wg, E. J. Benjamin, M. J. Blaha et al., "Heart disease and stroke statistics-2017 update: a report from the American Heart Association," Circulation, vol. 135, pp. 146-163, 2017.

[3] I. Liguori, G. Russo, F. Curcio et al., "Oxidative stress, aging, and diseases," Clinical Interventions in Aging, vol. Volume 13, pp. 757-772, 2018.

[4] W. H. W. Tang, T. Kitai, and S. L. Hazen, "Gut microbiota in cardiovascular health and disease," Circulation Research, vol. 120, no. 7, pp. 1183-1196, 2017.

[5] O. J. Ziff and D. Kotecha, "Digoxin: the good and the bad," Trends in Cardiovascular Medicine, vol. 26, no. 7, pp. 585595, 2016.

[6] J. R. Giudicessi, M. J. Ackerman, and M. Camilleri, "Cardiovascular safety of prokinetic agents: a focus on druginduced arrhythmias," Neurogastroenterology and Motility, vol. 30, no. 6, article e13302, 2018.

[7] V. Miller, A. Mente, M. Dehghan et al., "Fruit, vegetable, and legume intake, and cardiovascular disease and deaths in 18 countries (PURE): a prospective cohort study," Lancet, vol. 390, no. 10107, pp. 2037-2049, 2017.

[8] H. Rouhi-Boroujeni, E. Heidarian, H. Rouhi-Boroujeni, F. Deris, and M. Rafieian-Kopaei, "Medicinal plants with multiple effects on cardiovascular diseases: a systematic review," Current Pharmaceutical Design, vol. 23, pp. 9991015, 2017.

[9] G. Y. Tang, X. Meng, Y. Li, C. N. Zhao, Q. Liu, and H. B. Li, "Effects of vegetables on cardiovascular diseases and related mechanisms," Nutrients, vol. 9, no. 8, p. 857, 2017.

[10] X. Y. Xu, X. Meng, S. Li, R. Y. Gan, Y. Li, and H. B. Li, "Bioactivity, health benefits, and related molecular mechanisms of curcumin: current progress, challenges, and perspectives," Nutrients, vol. 10, no. 10, p. 1553, 2018.

[11] Q. Q. Mao, X. Y. Xu, S. Y. Cao et al., "Bioactive compounds and bioactivities of ginger (Zingiber officinale Roscoe)," Food, vol. 8, no. 6, p. 185, 2019.

[12] A. Shang, R. Y. Gan, X. Y. Xu, Q. Q. Mao, P. Z. Zhang, and H. B. Li, "Effects and mechanisms of edible and medicinal plants on obesity: an updated review," Critical Reviews in Food Science and Nutrition, pp. 1-17, 2020, In press.

[13] S. Y. Cao, B. Y. Li, R. Y. Gan et al., "The in vivo antioxidant and hepatoprotective actions of selected Chinese teas," Food, vol. 9, no. 3, p. 262, 2020.

[14] J. Tao, S. Li, R. Y. Gan, C. N. Zhao, X. Meng, and H. B. Li, "Targeting gut microbiota with dietary components on cancer: effects and potential mechanisms of action," Critical Reviews in Food Science and Nutrition, vol. 60, no. 6, pp. 1025-1037, 2020.

[15] X. Y. Xu, C. N. Zhao, S. Y. Cao, G. Y. Tang, R. Y. Gan, and H. B. Li, "Effects and mechanisms of tea for the prevention and management of cancers: an updated review," Critical Reviews in Food Science and Nutrition, vol. 60, no. 10, pp. 1693-1705, 2020.

[16] X. Y. Xu, J. Zheng, J. M. Meng et al., "Effects of food processing on in vivo antioxidant and hepatoprotective properties of green tea extracts," Antioxidants, vol. 8, no. 12, p. 572, 2019.

[17] S. Y. Cao, C. N. Zhao, X. Y. Xu et al., "Dietary plants, gut microbiota, and obesity: effects and mechanisms," Trends in Food Science and Technology, vol. 92, pp. 194-204, 2019.

[18] B. Y. Li, X. Y. Xu, R. Y. Gan et al., “Targeting gut microbiota for the prevention and management of diabetes mellitus by dietary natural products," Food, vol. 8, no. 10, p. 440, 2019.
[19] X. Meng, Y. Li, S. Li, R. Y. Gan, and H. B. Li, "Natural products for prevention and treatment of chemical-induced liver injuries," Comprehensive Reviews in Food Science and Food Safety, vol. 17, no. 2, pp. 472-495, 2018.

[20] Q. Liu, X. Meng, Y. Li et al., "Natural products for the prevention and management of Helicobacter pylori infection," Comprehensive Reviews in Food Science and Food Safety, vol. 17, no. 4, pp. 937-952, 2018.

[21] S. A. Lule, B. Namara, H. Akurut et al., "Blood pressure risk factors in early adolescents: results from a Ugandan birth cohort," Journal of Human Hypertension, vol. 33, no. 9, pp. 679-692, 2019.

[22] E. Bitok and J. Sabate, "Nuts and cardiovascular disease," Progress in Cardiovascular Diseases, vol. 61, no. 1, pp. 3337, 2018.

[23] C. N. Zhao, X. Meng, Y. Li et al., "Fruits for prevention and treatment of cardiovascular diseases," Nutrients, vol. 9, no. 6, p. 598, 2017.

[24] A. I. Olagunju, O. S. Omoba, V. N. Enujiugha, A. M. Alashi, and R. E. Aluko, "Antioxidant properties, ACE/renin inhibitory activities of pigeon pea hydrolysates and effects on systolic blood pressure of spontaneously hypertensive rats," Food Science \& Nutrition, vol. 6, no. 7, pp. 1879-1889, 2018.

[25] A. Mahmood, R. A. Sarfraz, I. A. Bhatti, and F. Hussain, "Alpha-amylase inhibitory activity and blood glucose and lipid-lowering potential of Heliotropium strigosum," Oxidation Communications, vol. 39, pp. 108-117, 2016.

[26] N. Cujic, K. Savikin, Z. Miloradovic et al., "Characterization of dried chokeberry fruit extract and its chronic effects on blood pressure and oxidative stress in spontaneously hypertensive rats," Journal of Functional Foods, vol. 44, pp. 330339, 2018.

[27] S. W. Park, K. C. Shin, S.-K. Yoou et al., "Effects of an ethanolic extract of mulberry fruit on blood pressure and vascular remodeling in spontaneous hypertensive rats," Clinical and Experimental Hypertension, vol. 41, pp. 280-286, 2019.

[28] F. Li, T. Zhang, Y. He et al., "Inflammation inhibition and gut microbiota regulation by TSG to combat atherosclerosis in ApoE $^{-1-}$ mice," Journal of Ethnopharmacology, vol. 247, p. 112232, 2020.

[29] A. M. al-Taweel, M. Raish, S. Perveen et al., “_Nepeta deflersiana_ attenuates isoproterenol-induced myocardial injuries in rats: Possible involvement of oxidative stress, apoptosis, inflammation through nuclear factor (NF)- $\kappa \beta$ downregulation," Phytomedicine, vol. 34, pp. 67-75, 2017.

[30] M. Jayachandran, S. S. M. Chung, and B. Xu, "A critical review on diet-induced microbiota changes and cardiovascular diseases," Critical Reviews in Food Science and Nutrition, vol. 60, pp. 2914-2925, 2019.

[31] G. Y. Tang, X. Meng, R. Y. Gan et al., "Health functions and related molecular mechanisms of tea components: an update review," International Journal of Molecular Sciences, vol. 20, no. 24, p. 6196, 2019.

[32] A. Shang, S. Y. Cao, X. Y. Xu et al., "Bioactive compounds and biological functions of garlic (Allium sativum L.)," Food, vol. 8, no. 7, p. 246, 2019.

[33] P. Azimi, R. Ghiasvand, A. Feizi et al., "Effect of cinnamon, cardamom, saffron and ginger consumption on blood pressure and a marker of endothelial function in patients with type 2 diabetes mellitus: a randomized controlled clinical trial," Blood Pressure, vol. 25, no. 3, pp. 133-140, 2016. 
[34] I. Peluso, A. Raguzzini, G. Catasta et al., "Effects of high consumption of vegetables on clinical, immunological, and antioxidant markers in subjects at risk of cardiovascular diseases," Oxidative Medicine and Cellular Longevity, vol. 2018, Article ID 5417165, 9 pages, 2018.

[35] Y. Yang, B. Dong, Z. Zou et al., "Association between vegetable consumption and blood pressure, stratified by BMI, among Chinese adolescents aged 13-17 years: a national cross-sectional study," Nutrients, vol. 10, no. 4, p. 451, 2018.

[36] B. Sun, X. Shi, T. Wang, and D. Zhang, "Exploration of the association between dietary fiber intake and hypertension among US adults using 2017 American College of Cardiology/American Heart Association Blood Pressure Guidelines: NHANES 2007-2014," Nutrients, vol. 10, p. 1091, 2018.

[37] Y. Kwon, "Association of curry consumption with blood lipids and glucose levels," Nutrition Research and Practice, vol. 10, no. 2, pp. 212-220, 2016.

[38] H. Du, L. Li, D. Bennett et al., "Fresh fruit consumption and major cardiovascular disease in China," The New England Journal of Medicine, vol. 374, pp. 1332-1343, 2016.

[39] Z. Bahadoran, P. Mirmiran, A. A. Momenan, and F. Azizi, "Allium vegetable intakes and the incidence of cardiovascular disease, hypertension, chronic kidney disease, and type 2 diabetes in adults: a longitudinal follow-up study," Journal of Hypertension, vol. 35, no. 9, pp. 1909-1916, 2017.

[40] P. Buil-Cosiales, M. A. Martinez-Gonzalez, M. Ruiz-Canela, J. Diez-Espino, A. Garcia-Arellano, and E. Toledo, "Consumption of fruit or fiber-fruit decreases the risk of cardiovascular disease in a Mediterranean young cohort," Nutrients, vol. 9, p. 295, 2017.

[41] P. Mirmiran, Z. Bahadoran, S. Khalili Moghadam, A. Zadeh Vakili, and F. Azizi, "A prospective study of different types of dietary fiber and risk of cardiovascular disease: Tehran lipid and glucose study," Nutrients, vol. 8, no. 11, p. 686, 2016.

[42] S. C. Larsson, N. Drca, M. Bjorck, M. Back, and A. Wolk, "Nut consumption and incidence of seven cardiovascular diseases," Heart, vol. 104, no. 19, pp. 1615-1620, 2018.

[43] T. B. Domingos, A. F. Pereira, E. M. Yokoo, and R. SallesCosta, "Low fruit consumption and omission of daily meals as risk factors for increased blood pressure in adults," The British Journal of Nutrition, vol. 116, no. 4, pp. 683-691, 2016.

[44] A. Cassidy, M. Bertoia, S. Chiuve, A. Flint, J. Forman, and E. B. Rimm, "Habitual intake of anthocyanins and flavanones and risk of cardiovascular disease in men," The American Journal of Clinical Nutrition, vol. 104, no. 3, pp. 587-594, 2016.

[45] J. S. Oh, H. Kim, A. Vijayakumar, O. Kwon, Y. Kim, and N. Chang, "Association of dietary flavonoid intake with prevalence of type 2 diabetes mellitus and cardiovascular disease risk factors in Korean women aged $\geq 30$ years," Journal of Nutritional Science and Vitaminology, vol. 63, no. 1, pp. 5158, 2017.

[46] X. Tian, H. Du, L. Li et al., "Fruit consumption and physical activity in relation to all-cause and cardiovascular mortality among 70,000 Chinese adults with pre-existing vascular disease," PLoS One, vol. 12, article e173054, 2017.

[47] H. A. Lee, D. Lim, K. Oh, E. J. Kim, and H. Park, "Mediating effects of metabolic factors on the association between fruit or vegetable intake and cardiovascular disease: the Korean National Health and Nutrition Examination Survey," BMJ Open, vol. 8, no. 2, article e019620, 2018.
[48] A. H. Liu, C. P. Bondonno, J. Russell et al., "Relationship of dietary nitrate intake from vegetables with cardiovascular disease mortality: a prospective study in a cohort of older Australians," European Journal of Nutrition, vol. 58, no. 7, pp. 2741-2753, 2019.

[49] G. Liu, M. Guasch-Ferre, Y. Hu et al., "Nut consumption in relation to cardiovascular disease incidence and mortality among patients with diabetes mellitus," Circulation Research, vol. 124, no. 6, pp. 920-929, 2019.

[50] M. Guasch-Ferre, X. Liu, V. S. Malik et al., "Nut consumption and risk of cardiovascular disease," Journal of the American College of Cardiology, vol. 70, no. 20, pp. 2519-2532, 2017.

[51] X. Liu, M. Guasch-Ferre, J.-P. Drouin-Chartier et al., "Changes in nut consumption and subsequent cardiovascular disease risk among US men and women: 3 large prospective cohort studies," Journal of the American Heart Association, vol. 9, article e013877, 2020.

[52] F. Nouri, N. Sarrafzadegan, N. Mohammadifard, M. Sadeghi, and M. Mansourian, "Intake of legumes and the risk of cardiovascular disease: frailty modeling of a prospective cohort study in the Iranian middle-aged and older population," European Journal of Clinical Nutrition, vol. 70, no. 2, pp. 217-221, 2016.

[53] M. K. Nsanya, B. B. Kavishe, D. Katende et al., "Prevalence of high blood pressure and associated factors among adolescents and young people in Tanzania and Uganda," Journal of Clinical Hypertension, vol. 21, pp. 470-478, 2019.

[54] S. Kimani, W. Mirie, M. Chege, O. T. Okube, and S. Muniu, "Association of lifestyle modification and pharmacological adherence on blood pressure control among patients with hypertension at Kenyatta National Hospital, Kenya: a crosssectional study," BMJ Open, vol. 9, article e023995, 2019.

[55] D. Stefler, S. Malyutina, Y. Nikitin et al., "Fruit, vegetable intake and blood pressure trajectories in older age," Journal of Human Hypertension, vol. 33, no. 9, pp. 671-678, 2019.

[56] T. B. Loader, C. G. Taylor, P. Zahradka, and P. J. H. Jones, "Chlorogenic acid from coffee beans: evaluating the evidence for a blood pressure-regulating health claim," Nutrition Reviews, vol. 75, pp. 114-133, 2017.

[57] D. Ettehad, C. A. Emdin, A. Kiran et al., "Blood pressure lowering for prevention of cardiovascular disease and death: a systematic review and meta-analysis," Lancet, vol. 387, no. 10022, pp. 957-967, 2016.

[58] M. R. Weir, J. I. Lakkis, B. Jaar et al., "Use of reninangiotensin system blockade in advanced CKD: an NKFKDOQI controversies report," American Journal of Kidney Diseases, vol. 72, no. 6, pp. 873-884, 2018.

[59] W. C. De Mello, "Local renin angiotensin aldosterone systems and cardiovascular diseases," Medical Clinics of North America, vol. 101, no. 1, pp. 117-127, 2017.

[60] M. Horiuchi, "The protective arm of renin angiotensin system: recent research progress and expectation for new therapeutic approach," Japanese Journal of Clinical Medicine, vol. 74, pp. 1583-1589, 2016.

[61] S. Y. Chay, A. Salleh, N. F. Sulaiman et al., "Blood-pressure lowering efficacy of winged bean seed hydrolysate in spontaneously hypertensive rats, peptide characterization and a toxicity study in Sprague-Dawley rats," Food \& Function, vol. 9, no. 3, pp. 1657-1671, 2018.

[62] O. A. Oluwagunwa, A. M. Alashi, and R. E. Aluko, "Solanum macrocarpon leaf extracts reduced blood pressure and heart 
rate after oral administration to spontaneously hypertensive rats," Current Topics in Nutraceutical Research, vol. 17, pp. 282-290, 2020.

[63] C. Gamboa-Gomez, I. F. Perez-Ramirez, A. Gonzalez-Gallardo, M. A. Gallegos-Corona, C. Ibarra-Alvarado, and R. ReynosoCamacho, "Effect of Citrus paradisi and Ocimum sanctum infusions on blood pressure regulation and its association with renal alterations in obese rats," Journal of Food Biochemistry, vol. 40, no. 3, pp. 345-357, 2016.

[64] U. Förstermann, N. Xia, and H. Li, "Roles of vascular oxidative stress and nitric oxide in the pathogenesis of atherosclerosis," Circulation Research, vol. 120, no. 4, pp. 713-735, 2017.

[65] C. Farah, L. Y. M. Michel, and J. L. Balligand, "Nitric oxide signalling in cardiovascular health and disease," Nature Reviews Cardiology, vol. 15, no. 5, pp. 292-316, 2018.

[66] A. Carrizzo, M. Ambrosio, A. Damato et al., "Morus albaextract modulates blood pressure homeostasis through eNOS signaling," Molecular Nutrition \& Food Research, vol. 60, no. 10 , pp. 2304-2311, 2016.

[67] C. Wang, W. Cheng, S. Bai et al., "White mulberry fruit polysaccharides enhance endothelial nitric oxide production to relax arteries in vitro and reduce blood pressure in vivo," Biomedicine \& Pharmacotherapy, vol. 116, p. 109022, 2019.

[68] Z. Pons, M. Margalef, F. I. Bravo, A. Arola-Arnal, and B. Muguerza, "Grape seed flavanols decrease blood pressure via Sirt-1 and confer a vasoprotective pattern in rats," Journal of Functional Foods, vol. 24, pp. 164-172, 2016.

[69] W. H. El-Tantawy and A. Temraz, "Natural products for controlling hyperlipidemia: review," Archives of Physiology and Biochemistry, vol. 125, pp. 128-135, 2018.

[70] S. A. Goldstein, A. D’Ottavio, T. Spears et al., "Causes of death and cardiovascular comorbidities in adults with congenital heart disease," Journal of the American Heart Association, vol. 9, article e016400, 2020.

[71] M. Gupta, C. Blumenthal, S. Chatterjee et al., "Novel emerging therapies in atherosclerosis targeting lipid metabolism," Expert Opinion on Investigational Drugs, vol. 29, pp. 611$622,2020$.

[72] N. S. Hadi, D. Lestari, A. Farmawati, A. Ghozali, and L. A. Lestari, "The relationship between systolic blood pressure and LDL cholesterol male Sprague Dawley rats given high fat diet and mung bean sprouts (Phaseolus radiatus L.)," in UGM Annual Scientific Conference Life Sciences 2016, pp. 26-35, Yogyakarta, Indonesia, October 2016.

[73] W. Febriani, A. Sulaeman, and B. Setiawan, "Red dragon fruit flour and exercise improve blood glucose and lipid profile in obese rats," Jurnal Gizi Dan Pangan, vol. 11, pp. 175-182, 2016.

[74] Hernawati, N. A. Setiawan, R. Shintawatin, and D. Priyandoko, "The role of red dragon fruit peel (Hylocereus polyrhizus) to improvement blood lipid levels of hyperlipidaemia male mice," in 4th International Seminar of Mathematics, Science and Computer Science Education, S. Aisyah, A. Samsudin, D. AlJupri Kusumawaty, E. Nuraeni, K. Yulianti, L. Hasanah, L. Rusyati, R. Megasari, and R. Rosjanuardi Wiji, Eds., p. 1013, Indonesia Univ Educ, Fac Math \& Sci Educ, Bandung, Indonesia, 2018.

[75] P. N. Ani and P. C. Aginam, "Effect of Citrus maxima juice on fasting blood glucose, lipid profile, liver enzyme and body weight," Nutrition \& Food Science, vol. 48, no. 5, pp. 755$763,2018$.
[76] U. Rohajatien, H. Harijono, T. Estiasih, and E. Sriwahyuni, "Bitter melon (Momordica charantia L.) fruit decreased blood glucose level and improved lipid profile of streptozotocin induced hyperglycemia rats," Current Research in Nutrition and Food Science Journal, vol. 6, no. 2, pp. 359-370, 2018.

[77] P. Pignatelli, D. Menichelli, D. Pastori, and F. Violi, "Oxidative stress and cardiovascular disease: new insights," Kardiologia Polska, vol. 76, no. 4, pp. 713-722, 2018.

[78] A. J. Kattoor, N. V. K. Pothineni, D. Palagiri, and J. L. Mehta, "Oxidative stress in atherosclerosis," Current Atherosclerosis Reports, vol. 19, no. 11, p. 42, 2017.

[79] X. Yang, Y. Li, Y. Li et al., "Oxidative stress-mediated atherosclerosis: mechanisms and therapies," Frontiers in Physiology, vol. 8, p. 600, 2017.

[80] H. Zhang and C. K. Zhai, "Effects of Chinese and North American wild rice on blood lipids, oxidative stress, and inflammation factors in hyperlipidemic rats," Cereal Chemistry, vol. 93, no. 4, pp. 357-363, 2016.

[81] M. Ciocoiu, M. Badescu, O. Badulescu, and L. Badescu, "The beneficial effects on blood pressure, dyslipidemia and oxidative stress of Sambucus nigra extract associated with renin inhibitors," Pharmaceutical Biology, vol. 54, no. 12, pp. 3063-3067, 2016.

[82] K. Dziadek, A. Kopec, and E. Piatkowska, "Intake of fruit and leaves of sweet cherry beneficially affects lipid metabolism, oxidative stress and inflammation in Wistar rats fed with high fat-cholesterol diet," Journal of Functional Foods, vol. 57, pp. 31-39, 2019.

[83] K. Senaphan, W. Sangartit, P. Pakdeechote et al., "Rice bran protein hydrolysates reduce arterial stiffening, vascular remodeling and oxidative stress in rats fed a highcarbohydrate and high-fat diet," European Journal of Nutrition, vol. 57, no. 1, pp. 219-230, 2018.

[84] A. Feriani, M. Tir, A. M. Gómez-Caravaca et al., "HPLCDAD-ESI-QTOF-MS/MS profiling of Zygophyllum album roots extract and assessment of its cardioprotective effect against deltamethrin-induced myocardial injuries in rat, by suppression of oxidative stress-related inflammation and apoptosis via NF- $\kappa \beta$ signaling pathway," Journal of Ethnopharmacology, vol. 247, article 112266, 2020.

[85] A. F. G. Cicero, C. Caliceti, F. Fogacci et al., "Effect of apple polyphenols on vascular oxidative stress and endothelium function: a translational study," Molecular Nutrition \& Food Research, vol. 61, no. 11, article 1700373, 2017.

[86] R. J. Koene, A. E. Prizment, A. Blaes, and S. H. Konety, "Shared risk factors in cardiovascular disease and cancer," Circulation, vol. 133, no. 11, pp. 1104-1114, 2016.

[87] L. Ferrucci and E. Fabbri, "Inflammageing: chronic inflammation in ageing, cardiovascular disease, and frailty," Nature Reviews. Cardiology, vol. 15, no. 9, pp. 505-522, 2018.

[88] T. Li, X. Lu, Y. Sun, and X. Yang, "Effects of spinach nitrate on insulin resistance, endothelial dysfunction markers and inflammation in mice with high-fat and high-fructose consumption," Food \& Nutrition Research, vol. 60, no. 1, p. 32010, 2016.

[89] S. Vutharadhi, U. Jolapuram, and L. D. Kodidhela, "Nutraceutical inherent of_Spinacia oleracea_Linn. methanolic leaf extract ameliorates isoproterenol induced myocardial necrosis in male albino Wistar rats via mitigating inflammation," Biomedicine \& Pharmacotherapy, vol. 85, pp. 239-247, 2017. 
[90] A. Udomkasemsab, C. Ngamlerst, P. Adisakwattana, A. Aroonnual, R. Tungtrongchitr, and P. Prangthip, "Maoberry (Antidesma bunius) ameliorates oxidative stress and inflammation in cardiac tissues of rats fed a high-fat diet," BMC Complementary and Alternative Medicine, vol. 18, no. 1, p. 344, 2018.

[91] R. D. Hills Jr., B. A. Pontefract, H. R. Mishcon, C. A. Black, S. C. Sutton, and C. R. Theberge, "Gut microbiome: profound implications for diet and disease," Nutrients, vol. 11, p. 1613, 2019.

[92] H. Ohira, W. Tsutsui, and Y. Fujioka, "Are short chain fatty acids in gut microbiota defensive players for inflammation and atherosclerosis?," Journal of Atherosclerosis and Thrombosis, vol. 24, no. 7, pp. 660-672, 2017.

[93] F. S. Thomaz, F. Altemani, S. K. Panchal, S. Worrall, and M. D. Nitert, "The influence of wasabi on the gut microbiota of high-carbohydrate, high-fat diet-induced hypertensive Wistar rats," Journal of Human Hypertension, pp. 1-11, 2020, In press.

[94] Y. Peng, Y. Yan, P. Wan et al., "Effects of long-term intake of anthocyanins from Lycium ruthenicum Murray on the organism health and gut microbiota in vivo," Food Research International, vol. 130, article 108952, 2020.

[95] Z. L. Liao, B. H. Zeng, W. Wang et al., "Impact of the consumption of tea polyphenols on early atherosclerotic lesion formation and intestinal Bifidobacteria in high-fat-fed ApoE $^{-/-}$mice," Frontiers in Nutrition, vol. 3, p. 42, 2016.

[96] A. Gomes, C. Oudot, Macià et al., "Berry-enriched diet in salt-sensitive hypertensive rats: metabolic fate of (poly)phenols and the role of gut microbiota," Nutrients, vol. 11, no. 11, p. 2634, 2019.

[97] N. A. Azis, R. Agarwal, N. M. Ismail et al., "Blood pressure lowering effect of Ficus deltoidea var kunstleri in spontaneously hypertensive rats: possible involvement of reninangiotensin-aldosterone system, endothelial function and anti-oxidant system," Molecular Biology Reports, vol. 46, no. 3, pp. 2841-2849, 2019.

[98] W. Shi, R. Yuan, X. Chen et al., "Puerarin reduces blood pressure in spontaneously hypertensive rats by targeting eNOS," The American Journal of Chinese Medicine, vol. 47, pp. 1938, 2019.

[99] I. Bello, N. S. Usman, A. Dewa et al., "Blood pressure lowering effect and vascular activity of Phyllanthus niruri extract: the role of NO/cGMP signaling pathway and $\beta$-adrenoceptor mediated relaxation of isolated aortic rings," Journal of Ethnopharmacology, vol. 250, p. 112461, 2020.

[100] L. Ding, C. Jia, Y. Zhang et al., "Baicalin relaxes vascular smooth muscle and lowers blood pressure in spontaneously hypertensive rats," Biomedicine \& Pharmacotherapy, vol. 111, pp. 325-330, 2019.

[101] S. Kumari, R. Rakavi, and M. Mangaraj, "Effect of guava in blood glucose and lipid profile in healthy human subjects: a randomized controlled study," Journal of Clinical and Diagnostic Research: JCDR, vol. 10, pp. 4-7, 2016.

[102] H. Alatas, M. Sja'bani, M. Mustofa et al., "The effects of soursop supplementation on blood pressure, serum uric acid, and kidney function in a prehypertensive population in accordance with the 2017 ACC/AHA guideline," Journal of Human Hypertension, vol. 34, no. 3, pp. 223-232, 2020.

[103] A. C. D. Lima, C. Cecatti, M. P. Fidélix et al., "Effect of daily consumption of orange juice on the levels of blood glucose, lipids, and gut microbiota metabolites: controlled clinical trials," Journal of Medicinal Food, vol. 22, no. 2, pp. 202210, 2019.

[104] L. Bell and C. M. Williams, "A pilot dose-response study of the acute effects of haskap berry extract (Lonicera caerulea L.) on cognition, mood, and blood pressure in older adults," European Journal of Nutrition, vol. 58, no. 8, pp. 33253334, 2019.

[105] A. N. Osinska, B. Begier-Krasinska, P. Rzymski, A. Krasinska, A. Tykarski, and Z. Krasinski, "The influence of adding tomato extract and acetylsalicylic acid to hypotensive therapy on the daily blood pressure profiles of patients with arterial hypertension and high cardiovascular risk," Kardiochirurgia $i$ torakochirurgia polska $=$ Polish Journal of Cardio-Thoracic Surgery, vol. 14, pp. 245-252, 2017.

[106] L. Ormesher, J. E. Myers, C. Chmiel et al., "Effects of dietary nitrate supplementation, from beetroot juice, on blood pressure in hypertensive pregnant women: A randomised, double-blind, placebo- controlled feasibility trial," Nitric Oxide, vol. 80, pp. 37-44, 2018.

[107] M. Nishimura, M. Suzuki, R. Takahashi et al., "Daily ingestion of eggplant powder improves blood pressure and psychological state in stressed individuals: a randomized placebo-controlled study," Nutrients, vol. 11, no. 11, p. 2797, 2019.

[108] Y. Fatemeh, F. Siassi, A. Rahimi et al., "The effect of cardamom supplementation on serum lipids, glycemic indices and blood pressure in overweight and obese pre-diabetic women: a randomized controlled trial," Journal of Diabetes \& Metabolic Disorders, vol. 16, no. 1, p. 40, 2017.

[109] F. Nikaein, S. Babajafari, S. M. Mazloomi, M. Zibaeenezhad, and A. Zargaran, "The effects of Satureja hortensis L. dried leaves on serum sugar, lipid profiles, hs-CRP, and blood pressure in metabolic syndrome patients: a double-blind randomized clinical trial," Iranian Red Crescent Medical Journal, vol. 19, article e34931, 2017.

[110] A. Mansouri, A. S. Vahed, H. Shandadi, F. Dashtban, and A. Arbabisarjou, "The effect of garlic and cumin on blood pressure and glycosylated hemoglobin in patients with type 2 diabetes," Bali Medical Journal, vol. 7, no. 1, pp. 156-160, 2018.

[111] J. Lorenzon dos Santos, A. Schaan de Quadros, C. Weschenfelder, S. Bueno Garofallo, and A. Marcadenti, "Oxidative stress biomarkers, nut-related antioxidants, and cardiovascular disease," Nutrients, vol. 12, no. 3, p. 682, 2020.

[112] C. Alasalvar and B. W. Bolling, "Review of nut phytochemicals, fat-soluble bioactives, antioxidant components and health effects," The British Journal of Nutrition, vol. 113, pp. $68-78,2015$.

[113] J. C. Stevens-Barron, L. A. de la Rosa, A. Wall-Medrano et al., "Chemical composition and in vitro bioaccessibility of antioxidant phytochemicals from selected edible nuts," Nutrients, vol. 11, no. 10, p. 2303, 2019.

[114] J. Dhillon, S.-Y. Tan, and R. D. Mattes, "Almond consumption during energy restriction lowers truncal fat and blood pressure in compliant overweight or obese adults," The Journal of Nutrition, vol. 146, no. 12, pp. 2513-2519, 2016.

[115] C. L. Rock, S. W. Flatt, H.-S. Barkai, B. Pakiz, and D. D. Heath, "Walnut consumption in a weight reduction intervention: effects on body weight, biological measures, blood pressure and satiety," Nutrition Journal, vol. 16, no. 1, p. 76, 2017.

[116] V. Mohan, R. Gayathri, L. M. Jaacks et al., "Cashew nut consumption increases HDL cholesterol and reduces systolic blood pressure in Asian Indians with type 2 diabetes: a 12- 
week randomized controlled trial," The Journal of Nutrition, vol. 148, no. 1, pp. 63-69, 2018.

[117] N. Abbaspour, T. Roberts, S. Hooshmand, M. Kern, and M. Y. Hong, "Mixed nut consumption may improve cardiovascular disease risk factors in overweight and obese adults," Nutrients, vol. 11, p. 1488, 2019.

[118] H. Samavat, A. R. Newman, R. Wang, J.-M. Yuan, A. H. Wu, and M. S. Kurzer, "Effects of green tea catechin extract on serum lipids in postmenopausal women: a randomized, placebo-controlled clinical trial," The American Journal of Clinical Nutrition, vol. 104, no. 6, pp. 1671-1682, 2016.

[119] A. Orem, C. Alasalvar, B. Vanizor Kural et al., "Cardio-protective effects of phytosterol-enriched functional black tea in mild hypercholesterolemia subjects," Journal of Functional Foods, vol. 31, pp. 311-319, 2017.

[120] Y. Katanasaka, Y. Miyazaki, Y. Sunagawa et al., "Kosen-cha, a polymerized catechin-rich green tea, as a potential functional beverage for the reduction of body weight and cardiovascular risk factors: a pilot study in obese patients," Biological \& Pharmaceutical Bulletin, vol. 43, no. 4, pp. 675-681, 2020.

[121] R. V. Giglio, A. M. Patti, A. F. G. Cicero et al., "Polyphenols: potential use in the prevention and treatment of cardiovascular diseases," Current Pharmaceutical Design, vol. 24, no. 2, pp. 239-258, 2018.

[122] A. F. G. Cicero and A. Colletti, "Effects of carotenoids on health: are all the same? Results from clinical trials," Current Pharmaceutical Design, vol. 23, no. 17, pp. 2422-2427, 2017.

[123] M. Jalalyazdi, J. Ramezani, A. Izadi-Moud, F. Madani-Sani, S. Shahlaei, and S. S. Ghiasi, "Effect of Hibiscus sabdariffa on blood pressure in patients with stage 1 hypertension," Journal of Advanced Pharmaceutical Technology \& Research, vol. 10, no. 3, pp. 107-111, 2019.

[124] D. Thirunavukkarasu, N. H. Kirubamani, and M. B. Naidu, "The effect of soy flour intake on systemic blood pressure and glycemic control in post-menopausal women with prediabetes and prehypertension," Indian Journal of Pharmaceutical Education and Research, vol. 51, pp. 349-354, 2017.

[125] M.-Y. Liao, Y.-C. Shen, H.-F. Chiu et al., "Down-regulation of partial substitution for staple food by oat noodles on blood lipid levels: a randomized, double-blind, clinical trial," Journal of Food and Drug Analysis, vol. 27, no. 1, pp. 93-100, 2019.

[126] K. Kent, K. E. Charlton, A. Jenner, and S. Roodenrys, “Acute reduction in blood pressure following consumption of anthocyanin-rich cherry juice may be dose-interval dependant: a pilot cross-over study," International Journal of Food Sciences and Nutrition, vol. 67, pp. 47-52, 2015.

[127] A. Stockton, G. Farhat, G. J. McDougall, and E. A. S. Al-Dujaili, "Effect of pomegranate extract on blood pressure and anthropometry in adults: a double-blind placebo-controlled randomised clinical trial," Journal of Nutritional Science, vol. 6, article e39, 2017.

[128] E. O. Igwe, K. E. Charlton, S. Roodenrys, K. Kent, K. Fanning, and M. E. Netzel, "Anthocyanin-rich plum juice reduces ambulatory blood pressure but not acute cognitive function in younger and older adults: a pilot crossover dose-timing study," Nutrition Research, vol. 47, pp. 28-43, 2017.

[129] D. Nowak, M. Goslinski, A. Wesolowska, K. Berenda, and C. Poplawski, "Effects of acute consumption of noni and chokeberry juices vs. energy drinks on blood pressure, heart rate, and blood glucose in young adults," Evidence-Based Complementary and Alternative Medicine, vol. 2019, Article ID 6076751, 9 pages, 2019.
[130] S. Kemmner, G. Lorenz, J. Wobst et al., "Dietary nitrate load lowers blood pressure and renal resistive index in patients with chronic kidney disease: a pilot study," Nitric Oxide, vol. 64, pp. 7-15, 2017.

[131] C. P. Kerley, E. Dolan, P. E. James, and L. Cormican, "Dietary nitrate lowers ambulatory blood pressure in treated, uncontrolled hypertension: a 7-d, double-blind, randomised, placebo-controlled, cross-over trial," The British Journal of Nutrition, vol. 119, no. 6, pp. 658-663, 2018.

[132] E. N. Lainata, A. L. Mapanawang, and S. H. Husen, "Effect of lilin vegetable (Setaria palmifolia) against blood pressure decrease in pregnant women in Gosoma village Tobelo subdistrict North Halmahera," International Journal Of Health Medicine and Current Research, vol. 2, pp. 540-544, 2017.

[133] K. L. Jonvik, J. Nyakayiru, P. J. M. Pinckaers, J. M. G. Senden, L. J. C. van Loon, and L. B. Verdijk, "Nitrate-rich vegetables increase plasma nitrate and nitrite concentrations and lower blood pressure in healthy adults," The Journal of Nutrition, vol. 146, no. 5, pp. 986-993, 2016.

[134] R. N. Ndanuko, L. C. Tapsell, K. E. Charlton, E. P. Neale, and M. J. Batterham, "Effect of individualised dietary advice for weight loss supplemented with walnuts on blood pressure: the HealthTrack study," European Journal of Clinical Nutrition, vol. 72, no. 6, pp. 894-903, 2018.

[135] A. M. Tindall, C. J. McLimans, K. S. Petersen, P. M. KrisEtherton, and R. Lamendella, "Walnuts and vegetable oils containing oleic acid differentially affect the gut microbiota and associations with cardiovascular risk factors: follow-up of a randomized, controlled, feeding trial in adults at risk for cardiovascular disease," The Journal of Nutrition, vol. 150, no. 4, pp. 806-817, 2020.

[136] D. J. Baer and J. A. Novotny, "Consumption of cashew nuts does not influence blood lipids or other markers of cardiovascular disease in humans: a randomized controlled trial," The American Journal of Clinical Nutrition, vol. 109, no. 2, pp. 269-275, 2019.

[137] N. Ishida, M. Iizuka, K. Kataoka et al., "Improvement of blood lipid profiles by Goishi tea polyphenols in a randomised, double-blind, placebo-controlled clinical study," International Journal of Food Sciences and Nutrition, vol. 69, no. 5, pp. 598-607, 2018.

[138] S. M. Abubakar, M. T. Ukeyima, J. P. E. Spencer, and J. A. Lovegrove, "Acute effects of Hibiscus sabdariffa calyces on postprandial blood pressure, vascular function, blood lipids, biomarkers of insulin resistance and inflammation in humans," Nutrients, vol. 11, no. 2, p. 341, 2019.

[139] F. Kaseb, Z. Yazdanpanah, A. N. Biregani, N. B. Yazdi, and Z. Yazdanpanah, "The effect of chamomile (Matricaria recutita L.) infusion on blood glucose, lipid profile and kidney function in Type 2 diabetic patients: a randomized clinical trial," Progress in Food \& Nutrition Science, vol. 20, pp. 110-118, 2018.

[140] K. J. Li, E. C. Borresen, N. Jenkins-Puccetti, G. Luckasen, and E. P. Ryan, "Navy bean and rice bran intake alters the plasma metabolome of children at risk for cardiovascular disease," Frontiers in Nutrition, vol. 4, p. 71, 2018.

[141] H. Roshan, O. Nikpayam, M. Sedaghat, and G. Sohrab, "Effects of green coffee extract supplementation on anthropometric indices, glycaemic control, blood pressure, lipid profile, insulin resistance and appetite in patients with the metabolic syndrome: a randomised clinical trial," The British Journal of Nutrition, vol. 119, no. 3, pp. 250-258, 2018. 